\title{
Introduction to cyanobacteria
}

\author{
Leticia Vidal, Andreas Ballot, \\ Sandra M. F. O. Azevedo, Judit Padisák \\ and Martin Welker
}

\section{CONTENTS}

Introduction 163

3.1 Cell types and cell characteristics 164

3.2 Morphology of multicellular forms 168

3.3 Cyanobacterial pigments and colours 170

3.4 Secondary metabolites and cyanotoxins 171

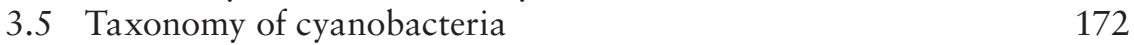

3.6 Major cyanobacterial groups 178

3.7 Description of common toxigenic and bloom-forming
cyanobacterial taxa

3.7.1 Filamentous forms with heterocytes 190

3.7.2 Filamentous forms without heterocytes and akinetes 195

3.7.3 Colonial forms 200

Picture credits 203

References 204

\section{INTRODUCTION}

Cyanobacteria are a very diverse group of prokaryotic organisms that thrive in almost every ecosystem on earth. In contrast to other prokaryotes (bacteria and archaea), they perform oxygenic photosynthesis and possess chlorophyll-a. Their closest relatives are purple bacteria (Woese et al., 1990; Cavalier-Smith, 2002) - and chloroplasts in higher plants (Moore et al., 2019). Photosynthetic activity of cyanobacteria is assumed to have changed the earth's atmosphere in the Proterozoic Era some 2.4 billion years ago during the so-called Great Oxygenation Event (Hamilton et al., 2016; Garcia-Pichel et al., 2019).

Historically, cyanobacteria were considered as plants or plant-like organisms and were termed "Schizophyceae", "Cyanophyta", "Cyanophyceae" or "blue-green algae". Since their prokaryotic nature has unambiguously been proven, the term "cyanobacteria" (or occasionally "cyanoprokaryotes") has been adopted in the scientific literature. A metagenomic study by Soo et al. (2017) revealed that cyanobacteria also comprise groups of 
nonphotosynthetic bacteria and the taxon Oxyphotobacteria is proposed for cyanobacteria in a strict sense. However, in this volume, the term "cyanobacteria" will be used for photosynthetic, oxygenic bacteria.

\section{I CELL TYPES AND CELL CHARACTERISTICS}

As prokaryotes, cyanobacteria lack a cell nucleus and other cell organelles, allowing their microscopic distinction from most other microalgae. In particular, cyanobacteria lack chloroplasts, and instead, the chlorophyll for the photosynthesis is contained in simple thylakoids, the site of the lightdependent reactions of photosynthesis (exception: Gloeobacter spp. not possessing thylakoids). Cyanobacteria occur as unicellular, colonial or multicellular filamentous forms. Diverse forms populate all possible environments where light and at least some water and nutrients are available - even if only in very low quantities. Examples for extreme environments in which cyanobacteria can be encountered are caves or deserts (Whitton \& Potts, 2000). This volume primarily considers cyanobacteria in the aquatic environments where they may grow suspended in water (i.e., as "plankton"), attached to hard surfaces ("benthos" or "benthic", respectively), or to macrophytes or any other submerged surfaces ("periphytic" or "metaphytic").

Sexual reproduction has not been observed for cyanobacteria; therefore, their only means of reproduction is asexual, through division of vegetative cells.

The morphology of cyanobacterial cells shows a number of characteristics that can be used for microscopic examination and identification: primarily, the shape and size of cells, subcellular structures and specialised cells (Figure 3.1-3.3). Cyanobacterial cells can be spherical, ellipsoid, barrelshaped, cylindrical, conical or disc-shaped. Some taxa include cells of different shapes. Cyanobacteria do not possess flagella, as are found in many other bacterial or phytoplankton taxa. Nevertheless, many cyanobacteria, in particular filamentous forms, show gliding motility, the mechanism of which is not yet fully understood (Hoiczyk, 2000; Read et al., 2007).

The size of cyanobacteria varies considerably between taxa: more or less spherical cells of unicellular cyanobacteria range in diameter from about $0.2 \mu \mathrm{m}$ to over $40 \mu \mathrm{m}$. In consequence, cell volume may vary by a factor of at least 300 000, making simple cell counts an unreliable parameter for the determination of biomass, especially when reported without differentiation between individual taxa (see Chapter 13). Some filamentous forms have been observed to have cell diameters of up to $100 \mu \mathrm{m}$, but as these coin-shaped cells are generally very short, their cell volume is not necessarily much larger than that of other species (Figure 3.2; Whitton \& Potts, 2000). The length of filaments (or trichomes; see below) can reach a few millimetres in certain benthic forms. Very small cells of cyanobacteria (in the size range $0.2-2 \mu \mathrm{m}$ ) have been recognised as a significant fraction of 
(a)

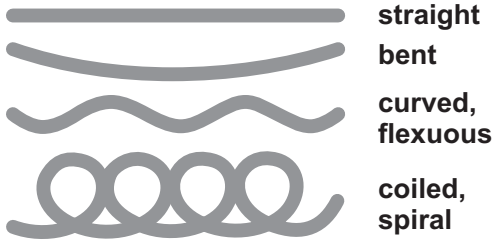

(b)

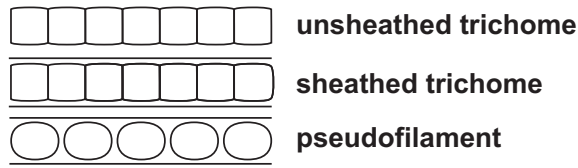

(c)

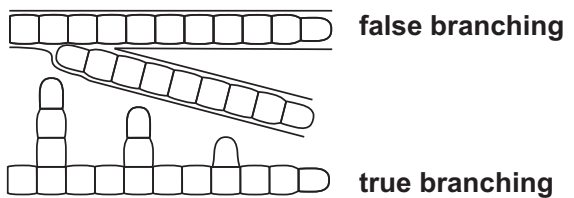

Figure 3.I Characteristics of cyanobacteria filaments. (a) General shapes; (b) presence of sheaths; (c) branching types.

(a)

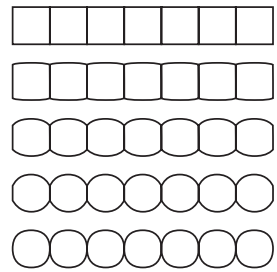

(b)
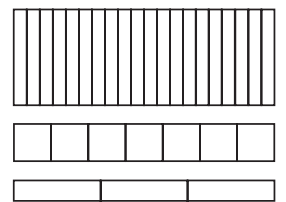

(c)

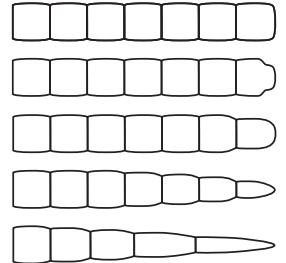

cylindrical, not constricted

cylindrical, slightly constricted

barrel shaped, constricted

elliptical, constricted

spherical

cell length $<<$ widths

cell length $\approx$ widths

cell length $\gg$ widths

not attenuated

terminal cell attenuated

slightly attenuated

attenuated

attenuated and elongated

Figure 3.2 Characteristics of cyanobacteria filaments. (a) Cell shapes and arrangement in filaments; (b) cell length-to-width ratios; (c) filament terminal region. 
(a)

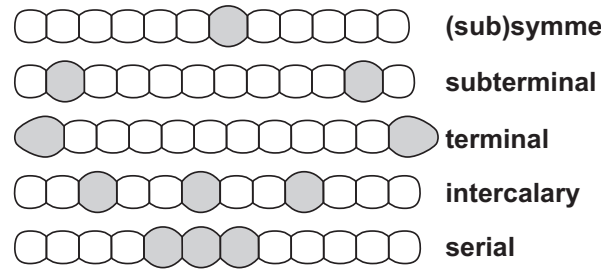

(b)

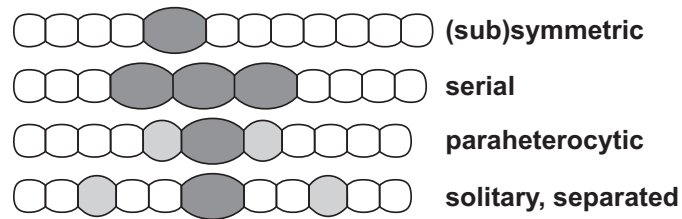

Figure 3.3 Arrangement of heterocytes (a) and akinetes (b) in filamentous cyanobacteria.

the so-called picoplankton in various freshwater and marine environments, such as Prochlorococcus that is found in huge numbers in the world's oceans (Flombaum et al., 2013). The occurrence of picocyanobacteria in freshwaters is well established (Postius \& Ernst, 1999; Stomp et al., 2007) but possibly is underestimated, especially when biomass estimates are based on microscopy. With molecular tools such as metagenomics (section 13.4), our understanding of the role of picocyanobacteria in lake ecosystems may increase (Śliwińska-Wilczewska et al., 2018; Nakayama et al., 2019).

A number of cyanobacterial taxa can (facultatively) produce so-called aerotopes that are clearly visible in microscopy as light-refracting structures. Aerotopes (sometimes incorrectly named "gas vacuoles" - they are not vacuoles in the cytological sense) are bundles of cylindrical protein microstructures that form the gas vesicles. These vesicles are filled with air entering the lumen by diffusion (see Walsby (1994) for an extensive review). Gas vesicles have a density of about one-tenth of that of water and thus render the entire cells less dense than water, providing buoyancy and making them float or emerge to the water surface (see Section 3.2). The gas vesicles measure some $75 \mathrm{~nm}$ in diameter and up to $1.0 \mu \mathrm{m}$ in length. The cylinders, capped by conical ends, are formed by a single wall layer of $2 \mathrm{~nm}$ thickness. The distribution of aerotopes within the cells is characteristic for individual taxa and can be used for identification by microscopical examination, but they can disintegrate after fixation with Lugol's solution (see Chapter 13).

Other subcellular (ultrastructural) characteristics such as the distribution of thylakoids are used in taxonomic studies (Hoffmann et al., 2005; Komárek et al., 2014). As thylakoids are not visible using light microscopy with standard equipment, other methodologies are generally applied for their examination, such as transmission electron microscopy.

In some groups of cyanobacteria (see Table 3.1), specialised cells occur, which are morphologically different from vegetative cells and which can be 
Table 3.I Major groups of cyanobacteria in the taxonomic schemes proposed by Castenholz et al. (200I) and Cavalier-Smith (2002)

\begin{tabular}{|c|c|c|}
\hline Group & Morphological characteristics & Genera (selection) \\
\hline $\begin{array}{l}\text { Subsection I } \\
\text { "Chroococcales" }\end{array}$ & $\begin{array}{l}\text { - Unicellular } \\
\text { - Colonies with regular or irregular } \\
\text { cell arrangement } \\
\text { - Embedded in extracellular mucilage }\end{array}$ & $\begin{array}{l}\text { Aphanocapsa, } \\
\text { Gomphospheria, } \\
\text { Merismopedia, Microcystis, } \\
\text { Synechococcus, } \\
\text { Synechocystis, Woronichinia }\end{array}$ \\
\hline $\begin{array}{l}\text { Subsection } 2 \\
\text { "Pleurocapsales" }\end{array}$ & $\begin{array}{l}\text { - Colonial or filamentous } \\
\text { - Reproduction through baeocytes }\end{array}$ & $\begin{array}{l}\text { Pleurocapsa, } \\
\text { Chroococcidiopsis, } \\
\text { Cyanocystis }\end{array}$ \\
\hline $\begin{array}{l}\text { Subsection } 3 \\
\text { "Oscillatoriales" }\end{array}$ & $\begin{array}{l}\text { - Multiplication by hormogonia } \\
\text { - Unbranched, linear filaments } \\
\text { - No heterocytes or akinetes } \\
\text { - Cells typically shorter than broad }\end{array}$ & $\begin{array}{l}\text { Leptolyngbya, Lyngbya, } \\
\text { Microcoleus, Oscillatoria, } \\
\text { Phormidium, Planktothrix, } \\
\text { Pseudanabaena,Tychonema }\end{array}$ \\
\hline $\begin{array}{l}\text { Subsection } 4 \\
\text { "Nostocales" }\end{array}$ & $\begin{array}{l}\text { - Multiplication by hormogonia } \\
\text { - Nonbranching or false branching } \\
\text { - Heterocytes (can be absent in } \\
\text { individual filaments) } \\
\text { - Akinetes }\end{array}$ & $\begin{array}{l}\text { Anabaena, Aphanizomenon, } \\
\text { Raphidiopsis } \\
\text { (Cylindrospermopsis), } \\
\text { Cuspidothrix, Chrysosporum, } \\
\text { Dolichospermum, Nostoc, } \\
\text { Sphaerospermopsis }\end{array}$ \\
\hline $\begin{array}{l}\text { Subsection } 5 \\
\text { "Stigonematales" }\end{array}$ & $\begin{array}{l}\text { - Multiplication by hormogonia } \\
\text { - True branching } \\
\text { - Heterocytes (can be absent in } \\
\text { individual filaments) } \\
\text { - Akinetes }\end{array}$ & $\begin{array}{l}\text { Chlorogloeopsis, Fischerella, } \\
\text { Stigonema }\end{array}$ \\
\hline
\end{tabular}

The morphological characteristics are based on microscopic observation. Exemplary genera are given for subsections.

generally easily recognised by light microscopy (see examples below), that is, heterocytes and akinetes.

Heterocytes are specialised cells that allow the fixation of atmospheric nitrogen, a process also called diazotrophy that involves nitrogenases, enzymes capable to reduce nitrogen to ammonium (Berman-Frank et al., 2003). Note that "heterocyte" is the more appropriate term than the traditionally used term "heterocyst" because a "cyst" has another, clearly defined meaning in cytology. Both terms may be seen as synonyms, while in this volume the term "heterocyte" is preferred.

Heterocytes lack the complete photosynthetic apparatus, thus avoiding the production of oxygen which would irreversibly damage nitrogenases (Bothe et al., 2010). Further, they possess a thickened cell wall, which further supports the anoxic intracellular milieu needed for diazotrophy.

Heterocytes often differ in size and shape from vegetative cells. In the microscope, they are generally easily recognised due to their different size and light refraction properties. Their number and the location of heterocytes in filaments can be used for taxonomic determination (Figure 3.3), although heterocyte formation depends on environmental 
and physiological conditions and may hence vary. They may be completely absent under conditions of ample availability of inorganic nitrogen. For example, Aphanizomenon spp. without heterocytes may be confused with Planktothrix agardhii if the terminal cells of the filaments are not examined carefully. Some authors suggested that Raphidiopsis spp. could be a nonheterocytous stage or type of Cylindrospermopsis spp. as recent studies showed both taxa to be phylogenetically very close (Moustaka-Gouni et al., 2009) and should hence be combined (Aguilera et al., 2018).

Akinetes are resting stages that can be found in the same taxa that form heterocytes. They are characterised by a generally (much) larger size compared to vegetative cells and different light refraction in microscopic view. Their cell wall is multilayered, and they often contain granules of glycogen and cyanophycin but generally no polyphosphate granules. Akinete formation and germination is triggered by environmental conditions (Adams \& Duggan, 1999).

The position, number and distribution of the heterocytes and akinetes are important morphological characteristics of species and genera. Heterocytes can be in an intercalary position between vegetative cells, that is, in the middle of a trichome, or terminal or subterminal. Akinetes are in an intercalary or subterminal position but generally not terminal. Because the formation of heterocytes and akinetes is triggered by environmental conditions, individual species can appear variable in natural samples or strain cultures. The distribution of these specialised cells also determines the symmetry of the trichome.

\subsection{MORPHOLOGY OF MULTICELLULAR FORMS}

Most cyanobacterial taxa form multicellular aggregates, and the size and shape of which can be used for the identification of cyanobacteria in freshly collected field samples. In conserved samples, however, these aggregates may disintegrate, rendering identification more difficult (see Chapter 13).

One important characteristic for identification is the type of cell division and the separation of cells following division - or the lack thereof.

In unicellular forms (e.g., Synechococcus sp.), dividing cells separate completely and do not form (true) filaments. Some "unicellular" species, however, can form microbial mats or colonies by embedding single cells in a mucous matrix (mucilage). In cultures, species forming colonies in natural environments often grow as singular cells or form aggregates with a morphology that differs clearly from that of naturally occurring colonies. Experimental studies with Microcystis sp. indicate that the presence of heterotrophic bacteria triggers the production of extracellular polysaccharide (EPS), a prerequisite for colony formation, while axenic strains generally grow as single cells (Shen et al., 2011; Wang et al., 2016).

In natural populations, colony morphology may change during the seasonal cycle (Reynolds et al., 1981). The arrangement of the cells in a colony can be completely irregular as a result of multiple cell division panes 
(a)

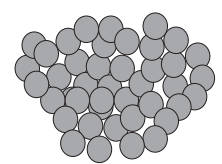

dense, irregular

(b)

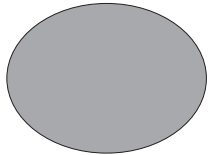

spherical/elliptical

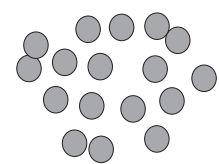

sparse, irregular

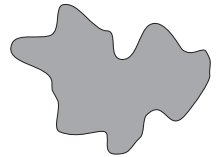

irregular

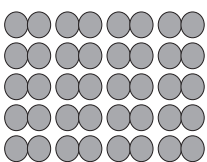

regular

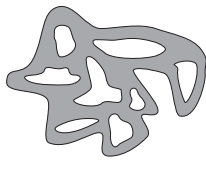

clathrate

Figure 3.4 Arrangement of cells in colonies (a) and overall shapes of colonies (b).

(e.g., most Microcystis sp.) or through series of cell divisions in only two panes, very regular, forming two-dimensional sheets (e.g., Merismopedia, Figure 3.4). Colonies can be composed of hundreds or even thousands of cells and reach sizes of some hundred micrometres to a few millimetres, visible with the naked eye. A particular colony form is given when cell division occurs in a single pane, leading to so-called pseudo-filaments, linear colonies of singular cells in a mucilaginous sheath, for example, in Cyanodictyon spp.

In filamentous forms, cells remain adhered to each other after division, forming chains of connected cells termed "trichomes". Trichomes can be enveloped in a mucous sheath in some taxa and are then called filaments (Figure 3.1). The general term hence is "trichome", but the term "filament" is often used interchangeably in the literature, as in this volume. Individual cells forming a trichome can be cylindrical, barrel-shaped or nearly spherical, and the corresponding trichomes appear either like a smooth thread or like a pearl necklace, respectively. Trichomes can be completely smooth with cell walls not visible or more or less deeply constricted (Figure 3.2). The cell shape is characteristic for different taxonomic groups, which can also represent different genera (Komárek, 2013). The length-to-width ratio of vegetative cells and the type of connections between them within trichomes are often characteristic for genera. In most filamentous taxa, cell division occurs only in a single division plane, resulting in filament growth by extension in only one dimension. From a single sheath, trichomes can protrude in multiple directions appearing as branched filaments. Such a "false" branching combines one-dimensional filaments in a multidimensional manner (e.g., Scytonema sp.). Some filamentous taxa perform cell division in more than one plane leading to a true branching (e.g., Fischerella sp.). Terminal vegetative cells in trichomes often show a shape and size distinctly different from that of cells within the filament (Figure 3.2). This includes elongation, tapered or pointed ends, swelling, or the covering with a calyptra, a mucilaginous, cap-like structure.

Multiple filaments can aggregate, forming macroscopically visible clusters. For example, under field conditions, Aphanizomenon flosaquae forms 
clusters (fascicles) with the shape and size similar to tiny conifer needles or blades of grass that can be easily recognised in water samples. In many Nostoc species, a large number of trichomes is embedded in a common mucilage forming large macroscopic structures of varying shapes (spheres in Nostoc pruniforme, sheets in N. commune or strings N. flagelliforme). Filaments of benthic cyanobacteria can aggregate to macroscopic clusters several decimetres long ("mermaids-hair" of marine Lyngbya spp.) or tufts that can completely cover hard surfaces (Phormidium spp. in streams or rivers).

Filamentous forms can form reproductive, motile units, the so-called hormogonia. They develop by fragmentation of trichomes and the release of short chains of cells from the immotile, unsheathed parental trichome. Hormogonial cells may or may not be different in size and shape from vegetative cells. They show active gliding motion when liberated from filaments and gradually develop into new filaments.

Baeocytes (also spelled beocytes) are small, spherical cells that arise from multiple fissions of a parental cell ("vegetative" cell) and are released after rupture of its fibrous outer wall layer. Baeocytes still contained in the parental cell wall appear as small colonies, and upon release, these reproductive cells develop into vegetative cells.

\subsection{CYANOBACTERIAL PIGMENTS AND COLOURS}

A key characteristic distinguishing cyanobacteria from other bacteria is that they possess chlorophyll- $a$ like plant chloroplasts, their major photosynthetic pigment and a variety of carotenoids, the latter acting primarily as photoprotectants to reduce oxidative damage to chlorophyll- $a$. In addition, cyanobacteria possess specific accessory pigments, the phycobilins (Tandeau de Marsac, 2003). These pigments are bound to water-soluble proteins, the phycobiliproteins, and occur in variants with different optical properties. Phycocyanin is common for all cyanobacteria and appears blue, giving a blue-green colour to many cyanobacteria, hence the classic name "blue-green algae". The blueish colour is especially prominent when cyanobacterial cells have lysed and dissolved phycocyanin stains the water blue. Phycoerythrin appears red and is responsible for the reddish or brownish colour of many cyanobacteria, such as Planktothrix rubescens. Within the cells, phycocyanins and phycoerythrins absorb certain wavelengths of photosynthetically active radiation (PAR) and transfer the light energy to chlorophyll- $a$ in photosystem II, thus extending the wavelength range of light available for photosynthesis (Berman-Frank et al., 2003). In some species, phycobilins are also present in the antenna of photosystem I where they are thought to serve the energy demand of nitrogen fixation (Watanabe et al., 2014).

Cyanobacterial cell colours vary from chartreuse to blue-green to violetred, depending on the ratio between phycocyanin, phycoerythrin, carotenoids 
and chlorophyll. By adapting this ratio, cyanobacteria may optimise their efficiency of exploitation of light energy (MacIntyre et al., 2002; Kehoe, 2010). Pigment ratios are often characteristic for a particular species but can also vary between clones or genotypes. They also vary in response to the light spectrum in which the cells (filaments, colonies) are growing, for example, with a higher share of red pigment (phycoerythrin) under conditions of low light intensity (Tandeau de Marsac, 1977; Acinas et al., 2009).

Cyanobacterial water blooms can have a wide variety of colours beyond the typical green or blue-green colour due to varying ratios of chlorophylls, phycocyanin, phycoerythrin and carotenoids. The latter are orange or red in colour, and they can be used to quantify phytoplankton groups, for example, by HPLC (high performance liquid chromatography) analysis of echinenone or canthaxanthin, which are specific for cyanobacteria (Frigaard et al., 1996; Takaichi, 2011). Surface blooms can appear orange, brownish, purple, and light green, among other colours, and have been occasionally reported as suspected "contamination with paint" due to their unexpected colour.

In addition to photosynthetic pigments, cyanobacteria can produce pigments that supposedly protect the cells from intense irradiation, in particular in the UV-wavelength range. These pigments can mask the colour of chlorophyll and phycocyanin, for example, scytonemin, a black pigment produced by Scytonema spp. (Dillon \& Castenholz, 1999).

\subsection{SECONDARY METABOLITES AND CYANOTOXINS}

Cyanobacteria can produce a large diversity of secondary metabolites. These are compounds produced by the cells that are not required for the basic cell metabolism, including the compounds considered as cyanobacterial toxins in this volume. These metabolites include polyketides, oligopeptides, lipids, alkaloids and other types of molecules. Many of them show bioactivity in various test systems, but their function for the cyanobacterial cells is not well understood (De Philippis \& Vincenzini, 1998; Burja et al., 2001; Gerwick et al., 2001; Welker \& von Döhren, 2006; Pereira et al., 2009). It is possible that among the multitude of yet poorly studied metabolites (see section 2.10), further compounds with adverse effects on higher plants and animals - or with therapeutic potential - will be identified in future (Vijayakumar \& Menakha, 2015).

A number of cyanobacterial metabolites are considered to serve as UV protection. Scytonemin, an aromatic indole alkaloid (Proteau et al., 1993), has been found primarily in filamentous, sheath-forming types exposed to high UV doses, such as the (semi)terrestrial Scytonema sp. (Dillon \& Castenholz, 1999). Mycosporine-like amino acids are a diverse family of compounds produced by fungi and several groups of eukaryotic phytoplankton (Oren \& Gunde-Cimerman, 2007) as well as by cyanobacteria, including Microcystis sp. (Liu et al., 2004; Pathak et al., 2019). 


\subsection{TAXONOMY OF CYANOBACTERIA}

As for all organisms, the key criteria for classifying cyanobacteria in a taxonomic system are phylogenetic relationships that should reflect the grouping of organisms in hierarchical taxa. Taxa (singular: taxon) are thus groups such as orders, families, genera, species, subspecies in which organisms are grouped so that they ideally share a common evolutionary ancestor. Historically, the taxonomic classification was inferred from morphological characteristics of cells and colonies studied by microscopy. In the last few decades, biochemical and molecular methods have been increasingly used in microbial taxonomy. Based on molecular data, a number of classical cyanobacterial taxa have been revised and renamed - and there will be more revisions in future (see Table 3.2).

Table 3.2 Cyanobacterial species names that underwent revision in recent years

\begin{tabular}{lll}
\hline New name & \multicolumn{1}{c}{ Old name (basionym) } & \multicolumn{1}{c}{ Reference } \\
\hline Chrysosporum bergii & Anabaena bergii & Zapomělová et al. (20I2) \\
Chrysosporum ovalisporum & Aphanizomenon ovalisporum & Zapomělová et al. (20I2) \\
Cuspidothrix issatchenkoi & Aphanizomenon issatchenkoi & Rajaniemi et al. (2005b) \\
Raphidiopsis raciborskii & Cylindrospermopsis raciborskii & Aguilera et al. (20I8) \\
Dolichospermum flosaquae & Anabaena flos-aquae & Wacklin et al. (2009) \\
Dolichospermum circinale & Anabaena circinalis & Wacklin et al. (2009) \\
Dolichospermum crassum & Anabaena crassa & Wacklin et al. (2009) \\
Dolichospermum lemmermannii & Anabaena lemmermannii & Wacklin et al. (2009) \\
Dolichospermum planctonicum & Anabaena planctonica & Wacklin et al. (2009) \\
Dolichospermum smithii & Anabaena smithii & Wacklin et al. (2009) \\
Dolichospermum solitarium & Anabaena solitaria & Wacklin et al. (2009) \\
Dolichospermum spiroides & Anabaena spiroides & Wacklin et al. (2009) \\
Dolichospermum viguieri & Anabaena viguieri & Wacklin et al. (2009) \\
Kamptonema formosum & Oscillatoria formosum & Strunecký et al. (20l4) \\
Moorea producens & Lyngbya majuscula & Engene et al. (20I2) \\
Microcoleus autumnalis & Phormidium autumnale & Strunecký et al. (20I3) \\
Microseira wollei & Lyngbya wollei & McGregor \& Sendall (20I5) \\
Planktothricoides raciborskii & Planktothrix raciborskii & Suda et al. (2002) \\
Sphaerospermopsis & Aphanizomenon & Zapomělová et al. (20II) \\
aphanizomenoides & aphanizomenoides & \\
Sphaerospermopsis reniformis & Anabaena reniformis & Zapomělová et al. (20II) \\
Wilmottia murrayi & Phormidium murrayi & Strunecký et al. (20II) \\
\hline
\end{tabular}

The list is not complete but comprises primarily those species that are potentially toxigenic or are closely related to toxigenic species. Note that a new name not necessarily comprises all forms previously published under the old name, and therefore, a retrospective renaming may be critical. 
A major challenge for cyanobacterial taxonomy is the lack of a clear concept or definition of a species. Commonly accepted species definitions generally used in bacteriology such as genomic DNA/DNA hybridisation or average nucleotide identity (ANI) are not easily applied to cyanobacteria because these methods require axenic cultures (i.e., pure, clonal cultures free of any other bacteria). For cyanobacteria, taxonomy is further complicated by the fact that two basically different systems of nomenclature have become established, the International Code of Nomenclature for algae, fungi, and plants (ICN) and the International Code of Nomenclature of Bacteria (ICNB) (see Box 3.1). As a consequence, the number of recognised species in a given sample can vary greatly, depending on the scientific background of the person identifying the species and counting them in the sample (Whitton \& Potts, 2000; Nabout et al., 2013).

\section{BOX 3.I: NOMENCLATURE OF CYANOBACTERIA: UNSOLVED ISSUES}

Historically, cyanobacteria were considered as algae. When their prokaryotic nature was revealed in the mid-20th century (Stanier \& Van Niel, 194I), many of the established genera had been already described following the International Code of Nomenclature for algae, fungi, and plants ("botanical code", ICN) - as it was historically the case with heterotrophic bacteria, too. While the nomenclature of heterotrophs and Archaea follows the International Code of Nomenclature of Bacteria ("bacteriological code", ICNB) from 1980 onwards, cyanobacterial nomenclature is treated by both the botanical code and the bacteriological code. Because this is a constant source of confusion, several solutions have been proposed but none found unanimous acceptance (Stanier et al., 1978). In 1985, the "Subcommittee on the Taxonomy of Phototrophic Bacteria" proposed to consider species validly published under the botanical code as valid species in the sense of the bacteriological code, but this proposal was never accepted and the debate is ongoing (Oren \& Ventura, 2017). The latest proposals take extreme positions for cyanobacteria, either exclusively following the botanical code (Oren \& Garrity, 2014) or exclusively following the bacteriological code (Pinevich, 2015). While taxonomic committees continue to search for a solution, the existing dual nomenclature has consequences in practice when studying toxic cyanobacteria (Komárek, 2006; Komárek, 20II; Gaget et al., 2015a; Gaget et al., 2015b; Dvořák et al., 2018).

Numbers of species: Following the bacterial code, only a very low number of cyanobacterial species are considered as valid bacterial species, while the number of species described following the botanical code is continuously 
increasing. However, the botanical code is difficult to follow because (botanically) valid descriptions are published in a large variety of scientific journals and not recorded in a central registry. As a result, no comprehensive list of globally accepted species is available.

Example: For the genus Microcystis, Algaebase (http://www.algaebase.org/) lists 5I "taxonomically accepted" species (and additionally 62 synonyms and species of unclear status), Cyano database (http://www.cyanodb.cz/) lists 2 species (M. aeruginosa and M. minutissima), the National Center for Biotechnology Information (NCBI) taxonomy browser (https://www.ncbi. nlm.nih.gov/taxonomy) lists 19 species for which sequences are deposited while the "list of prokaryotic names with standing in nomenclature" (LPSN, http://www.bacterio.net/index.html) lists 12 species (published under the ICN) but considers Microcystis aeruginosa as an illegitimate species name "in need of a replacement" (all accessed April 2020).

Type strains: Formal type strains are not required for species described following the rules of ICN, and in consequence, there are no reference genomic sequences available. This is critical especially for molecular studies that generally rely on designated type strains. Therefore, the taxonomic classification of a deposited sequence depends largely on the depositor's judgement - or misjudgement.

Example: The majority of nucleotide sequences deposited for the genus Anabaena in the NCBI GenBank is not assigned to a species, and among those assigned to a species, a large share is classified "cf." (from Latin "confer" referring to an unconfirmed classification), for example, Anabaena cf. circinalis (now Dolichospermum cf. circinale). Based on these database entries, a reliable molecular identification is not possible.

Global taxonomy: An unambiguous taxonomic scheme for ranks above genera is lacking. Higher ranks are variably labelled as order, sections or subgroups. None of the schemes is formally accepted by the International Committee on Systematics of Prokaryotes (ICSP).

Example: The order Oscillatoriales sensu Cavalier-Smith (2002) corresponds largely to Subsection III sensu Castenholz et al. (200I) and Section III sensu Rippka et al. (1979), each comprising a similar but not identical list of genera. It is not congruent with the order Oscillatoriales sensu (Komárek et al., 2014) that includes unicellular taxa like Cyanothece but excludes filamentous ones such as Leptolyngbya (see also Table 3.3). 


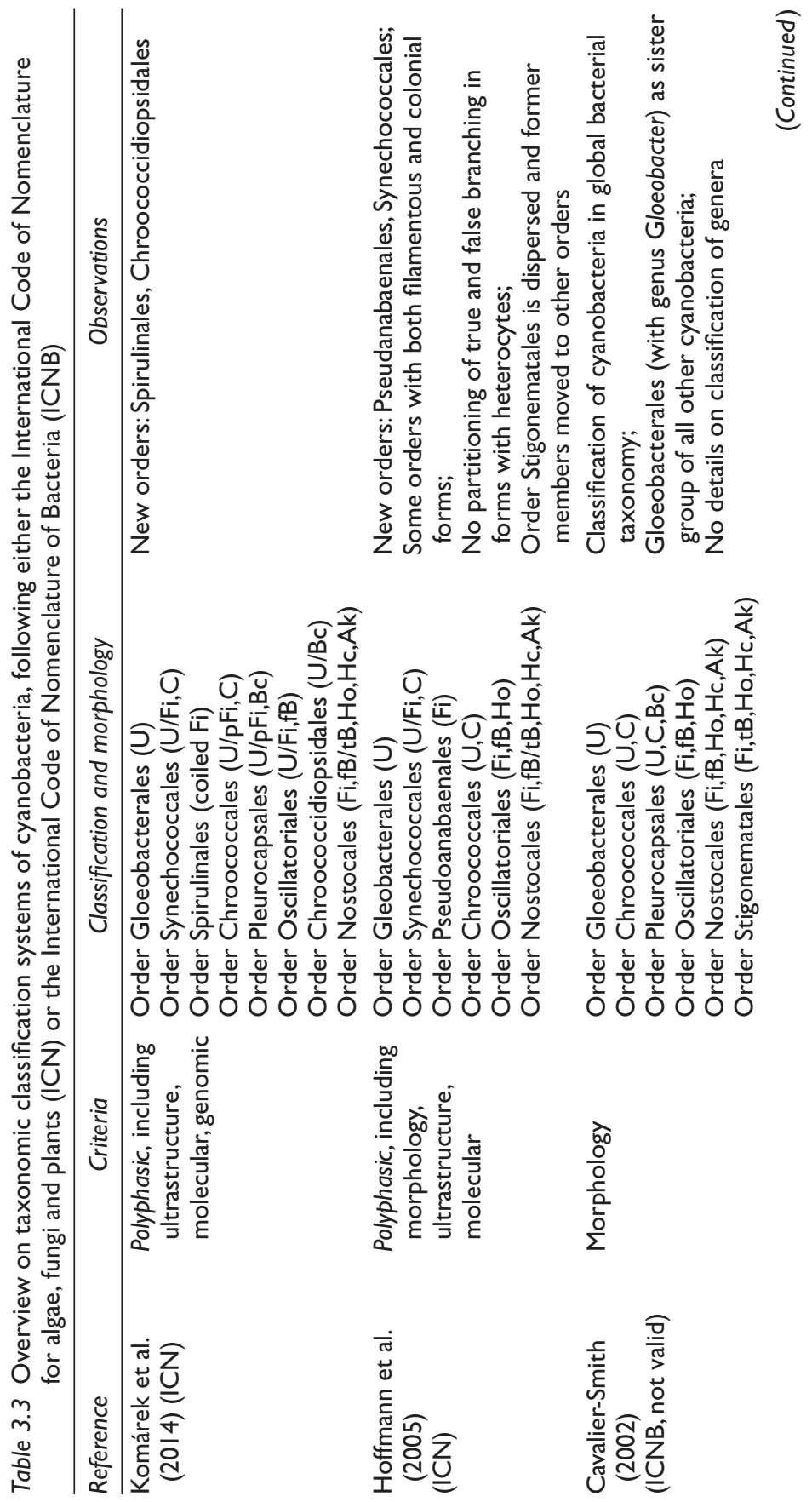




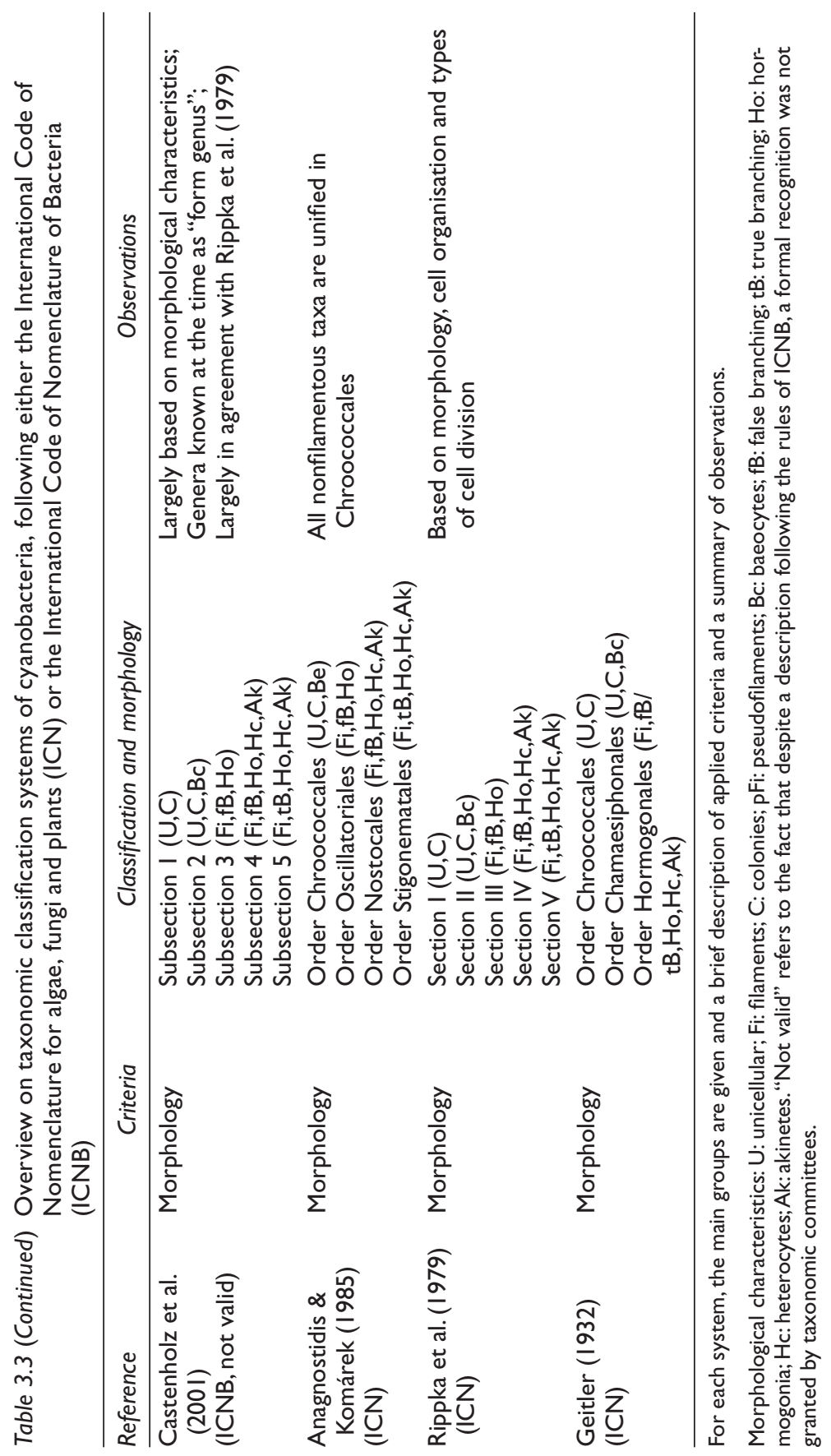


The multiple taxonomic systems are a constant source of confusion in academic discussions, albeit of less relevance for practitioners. Nevertheless, an essential understanding of the issue may help to appraise deviating views on taxonomic ratings and to understand why a particular organism is named variably in the literature.

Molecular approaches to cyanobacterial taxonomy are most promising for inferring true phylogenetic relationships. The methods applied involve sequencing of marker genes (16S rDNA, phycocyanin operon), DNA-DNA hybridisation, genome sequencing and biochemical characteristics (fatty acid profiles) or immunological procedures (Wilmotte, 1994; Whitton \& Potts, 2000). Preferably, molecular results are combined with other characteristics as the basis for a so-called polyphasic taxonomy approach (Vandamme et al., 1996; Komárek, 2016a; Wilmotte et al., 2017).

On the genus level, evolutionary trees based on 16S rRNA gene (Tomitani et al., 2006) sequences are largely in agreement with classifications based on morphological characteristics, in particular if these were re-evaluated and include ultrastructural characteristics (Hoffmann et al., 2005; Komárek, 2006), in particular, the structure and distribution of thylakoids (Mareš et al., 2019).

Most of the species descriptions in the currently available manuals and reference books are based on morphological traits that can be recognised by optical microscopy. Section 13.2 lists taxonomic reviews and keys for the determination of cyanobacteria, focusing on potentially toxigenic taxa. Although some classification systems based on morphological features were published before biochemical and molecular characteristics became important classification criteria, they are still being used (Table 3.2) because new criteria have not sufficiently been consolidated and, particularly, because the identification by microscopy has been the most accessible method for routine analyses. However, for identifying cyanobacteria, it should be considered that their morphological appearance can vary in response to actual growth conditions (phenotypic plasticity).

Today, most species of cyanobacteria have been described following the botanical code of nomenclature based on morphological criteria. Many of the older species descriptions are based on drawings and other pictures that hence cannot be used as fully objective criteria, especially since the botanical code does not require the deposition of a type strain. Possibly the description of cyanobacterial taxa by the bacteriological code would be biologically more appropriate (see Box 3.1) as there is no doubt that cyanobacteria are a monophyletic branch in the global bacterial phylogenetic tree (Woese, 1987; Pace, 1997).

The ambiguity of the definition of cyanobacterial species and the lack of accessible reference material for many species often hamper the unambiguous assignment of cyanobacteria in field samples to a species, especially when molecular methods are applied (section 13.4). For this reason, 
throughout this volume, taxonomic assignment to the genus level is given preference (e.g., Microcystis sp.). In some cases, a more precise identification of a dominant organism to the species level may be useful for a more accurate prediction of toxin occurrence. For example, Planktothrix agardbii and P. rubescens have both been shown to potentially contain microcystins, but may contain different analogues with different toxicity, typically occur in different types of waterbodies and usually can readily be distinguished by both their colour and cell dimensions.

Practitioners in health authorities with some experience in microscopy can easily learn to recognise the dominant cyanobacterial genera (and in some cases also species), which occur in the region they are monitoring. For a number of taxa, recent revisions have led to a renaming of common taxa, and in a few cases, changes in genus names require close attention for a certain period while old and new names may be used in parallel. Also, some taxa have been reorganised beyond simple renaming of a taxonomic entity. For example, while the organisms described as Moorea producens (Engene et al., 2012) formerly were named Lyngbya majuscula, we cannot be sure that all organisms referred to as L. majuscula in publications prior to 2010 would indeed be classified as M. producens today. In this book, we generally refer to the most recent names of species or genera as of 2019 (see Table 3.3 and Salmaso et al. (2016a)), but when referring to older literature, for which allocation of a taxon to the new name risks being wrong, we quote the former name.

In field samples, most cyanobacteria can be readily distinguished from other phytoplankton and particles under the microscope at a magnification of $100 \times$ to $400 \times$. The following section describes and depicts the most frequently occurring taxa known to produce toxins.

\subsection{MAJOR CYANOBACTERIAL GROUPS}

As outlined in Box 3.1, several taxonomic systems exist to group cyanobacteria in a taxonomic scheme as reviewed in more detail in Komárek et al. (2014). Table 3.3 summarises taxonomic schemes for cyanobacteria, starting from the early scheme proposed by Geitler (1932) to the most recent one proposed by Komárek et al. (2014). Several systems avoid the use of nomenclatural categories and instead use groups such as "sections" (Rippka et al., 1979) or "subsections" (Castenholz et al., 2001) instead of orders, discernible by the suffix "-ales" in order to reflect the understanding that at least some of these groups do not represent monophyletic units but are defined based on shared morphological characteristics (Ishida et al., 2001; Gugger \& Hoffmann, 2004). Based on rapidly increasing genomic sequence information from axenic strains, metagenomic studies and ultrastructural analyses, the taxonomy of cyanobacteria will most probably converge to a truly 
taxonomic system based on phylogenetic relationships in the near future (Shih et al., 2013).

The classification of taxa proposed by Komárek et al. (2014) is largely based on whole-genome sequences and on ultrastructural characteristics, such as the distribution of thylakoids in the cells. These characteristics are not observable with light microscopy and hence not helpful for the routine analysis of field samples. Further, in this system, classical and morphological characteristics easily observed by microscopy, such as formation of filaments or the presence of sheaths, are less important. For example, the filamentous genus Pseudanabaena is grouped together with the unicellular Synechococcus in a new order Synechococcales.

For practical purposes, such as the examination of high numbers of samples, earlier taxonomic systems appear more suitable. Therefore, in the following, the taxonomic scheme as proposed by Castenholz et al. (2001) is considered because characteristics like the arrangement of thylakoids or sequences of housekeeping genes are generally not available for monitoring purposes. It is also primarily based on morphological features observed by light microscopy and largely corresponds to the earlier scheme by Rippka et al. (1979) while including more genera. This scheme does not use the nomenclatural definition of categories such as orders and families but rather replaces these with "subsections", "families" and "form genera" that do not reflect monophyletic taxa (and thus is considered invalid in a system of nomenclature based on phylogenetic relationships). However, it provides a temporary system that has the advantage to be a practical, convenient and stable method for the microscopical identification of cyanobacterial strains and samples.

Nonetheless, for molecular methods (see section 13.4), a genome-based taxonomic scheme reflecting phylogenetic relationships may eventually prove to be more suitable, especially once designated type strains or sequences, respectively, are accessible.

\subsection{DESCRIPTION OF COMMON TOXIGENIC AND BLOOM-FORMING CYANOBACTERIAL TAXA}

The following brief descriptions of common toxigenic and bloom-forming cyanobacteria give an introduction which certainly cannot replace taxonomic keys for their identification (see Chapter 13). Also, the global diversity of cyanobacteria is higher by orders of magnitudes beyond the selection of taxa presented in this chapter. Also, the following section does not include a number of genera and species known to produce toxins but not to form blooms or benthic mats, for example, Umezakia sp. and Fischerella sp. For the illustration of morphological characteristics, see Figures 3.1-3.4. A regularly updated list of cyanobacterial taxa (and other algae) can be found in AlgaeBase (Guiry \& Guiry, 2019) and 
CyanoDB (Hauer \& Komárek, 2019). The following descriptions consider only morphological characteristics that can be observed by standard light microscopy. Figure 3.5A-U gives microscopic images for most of the taxa. For a brief description of further genera and a short summary of recent taxonomy of cyanobacteria, see also Dvořák et al. (2017).

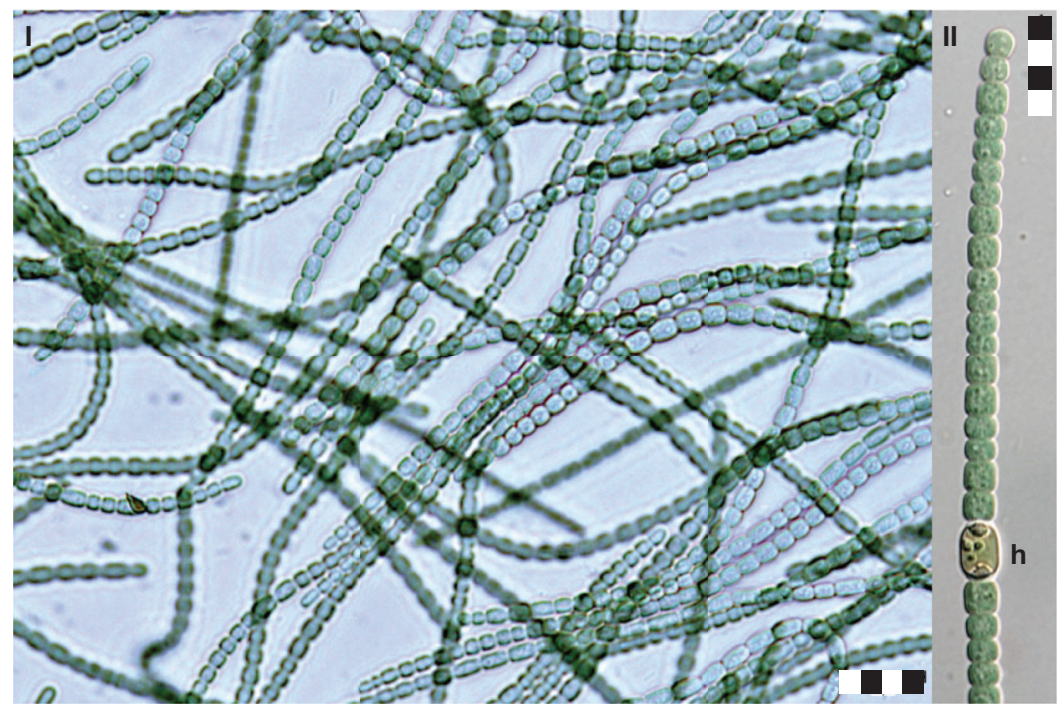

Figure 3.5A Anabaena sensu stricto sp. h: heterocyte. Units in scale bars correspond to 5 $\mu \mathrm{m}$. For origin of individual photographs, see the end of this chapter.

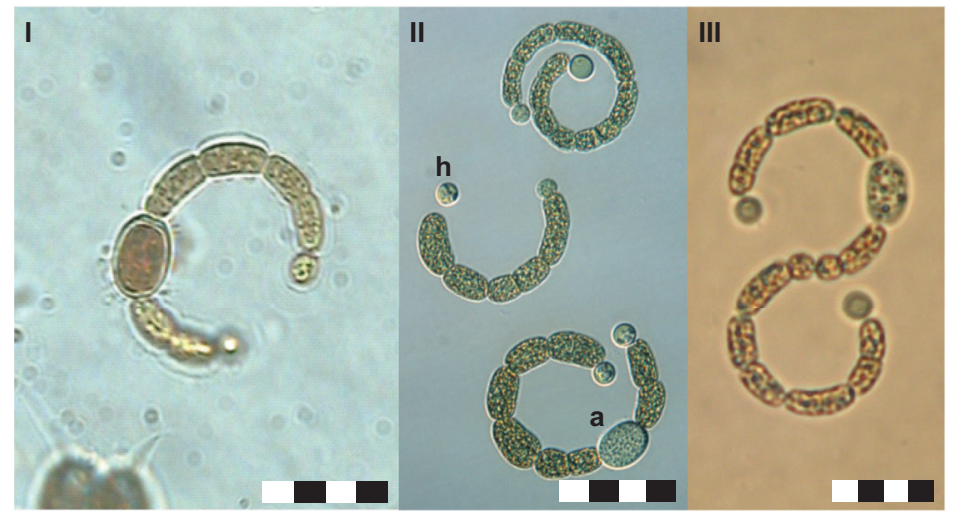

Figure 3.5B Anabaenopsis sp. Short, coiled trichomes with terminal heterocytes (h) and symmetric to subsymmetric akinetes (a). Units in scale bars correspond to $5 \mu \mathrm{m}$. For origin of individual photographs, see the end of this chapter. 


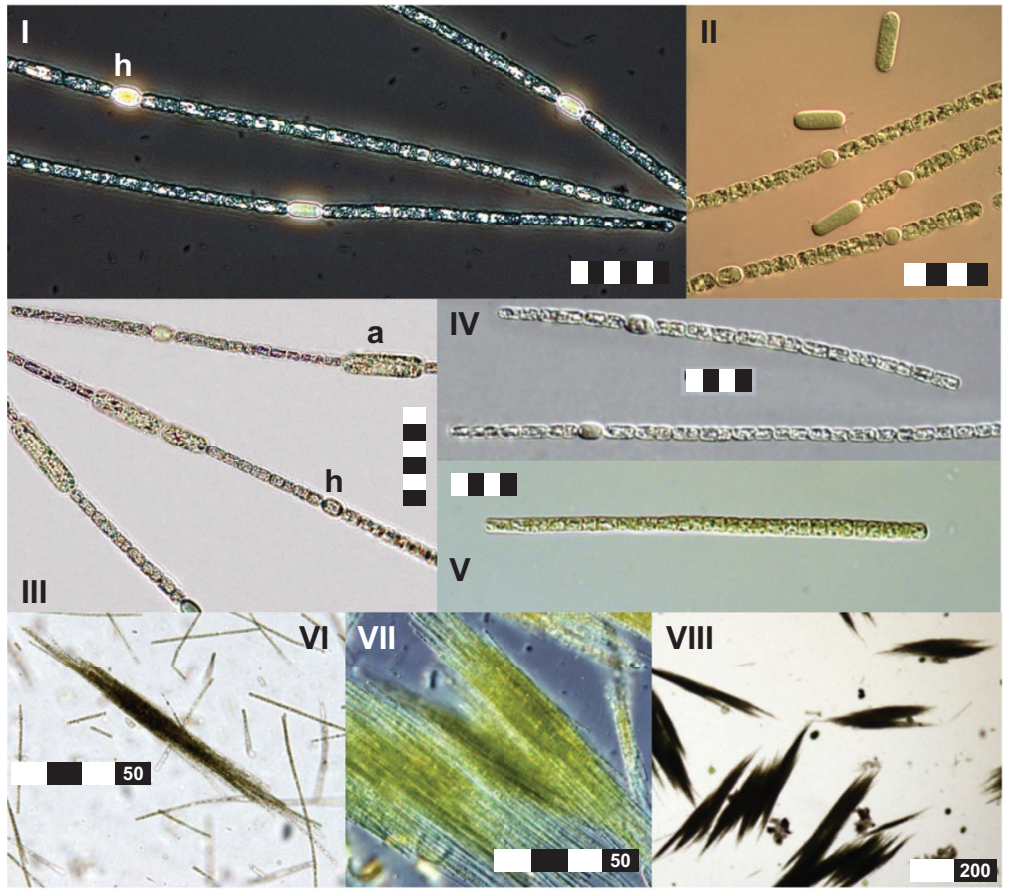

Figure 3.5C Aphanizomenon sp. In phase contrast, heterocytes appear highly refractory (I); aerotopes are homogeneously distributed in vegetative cells. Akinetes are much larger than vegetative cells and heterocytes (II-III) and can occur as single cells in cultures (II). Trichomes without heterocytes resemble Planktothrix sp. (V). Multiple trichomes of $A$. flosaquae aggregate to macroscopic fascicles (VI-VIII). Units in scale bars correspond to $5 \mu \mathrm{m}$ if not indicated otherwise. For origin of individual photographs, see the end of this chapter.

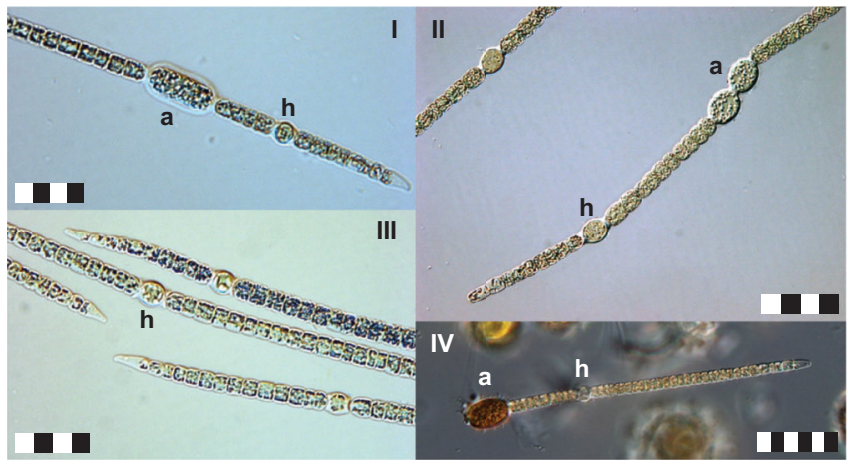

Figure 3.5D Chrysosporum sp. Terminal cells are pointed and appear hyaline. Akinetes (a) with distinctgranulae; h:heterocytes.Unitsinscalebarscorrespondto $5 \mu \mathrm{m}$.For origin of individual photographs, see the end of this chapter. 


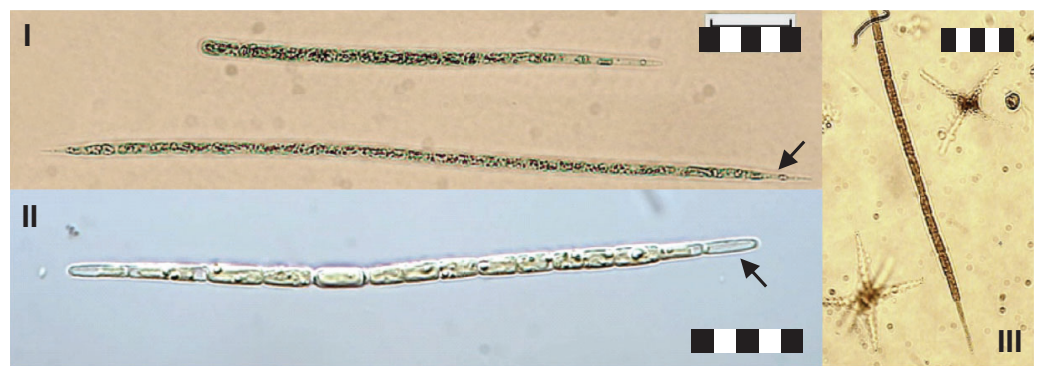

Figure 3.5E Cuspidothrix sp. Arrows point to attenuated and elongated terminal cells with hyaline content. Units in scale bars correspond to $5 \mu \mathrm{m}$. For origin of individual photographs, see the end of this chapter.

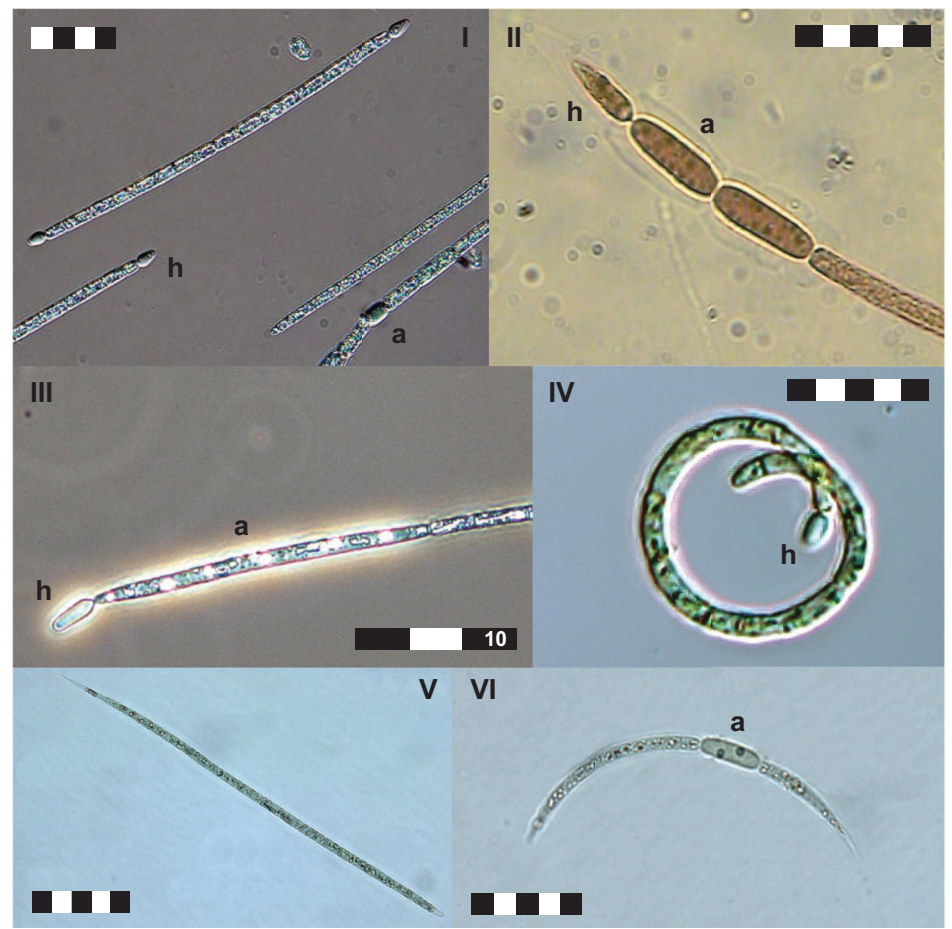

Figure 3.5F Raphidiopsis sp. with (Cylindrospermopsis; I-IV) and without (V-VI) heterocytes. Raphidiopsis has typical terminal heterocytes (h) when present. Akinetes (a) are larger than vegetative cells and often show distinct, large granulae. Units in scale bars correspond to $5 \mu \mathrm{m}$ if not indicated otherwise. For origin of individual photographs, see the end of this chapter. 

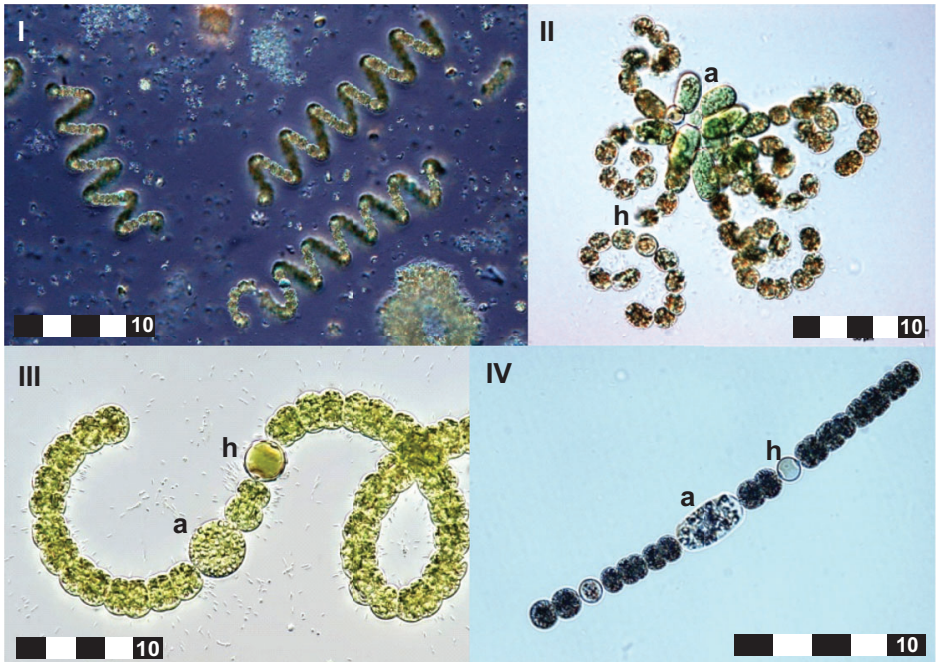

Figure 3.5G Dolichospermum sp. D. crassum (I), D. lemmermannii with aggregated akinetes (a) and short trichomes (II), D. mucosum (III) and D. planctonicum (IV). Heterocytes (h) with similar size than vegetative cells. Units in scale bars correspond to $10 \mu \mathrm{m}$. For origin of individual photographs, see the end of this chapter.

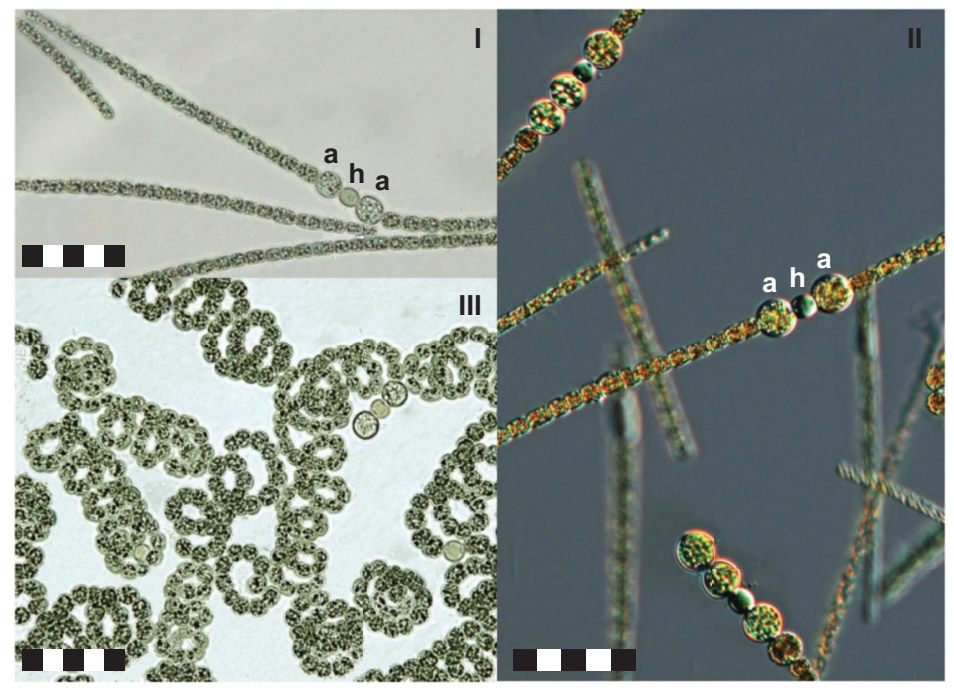

Figure 3.5H Sphaerospermopsis aphanizomenoides (I, II) and S. reniformis (III). Akinetes (a) typically next to heterocytes (h). Units in scale bars correspond to $5 \mu \mathrm{m}$. For origin of individual photographs, see the end of this chapter. 


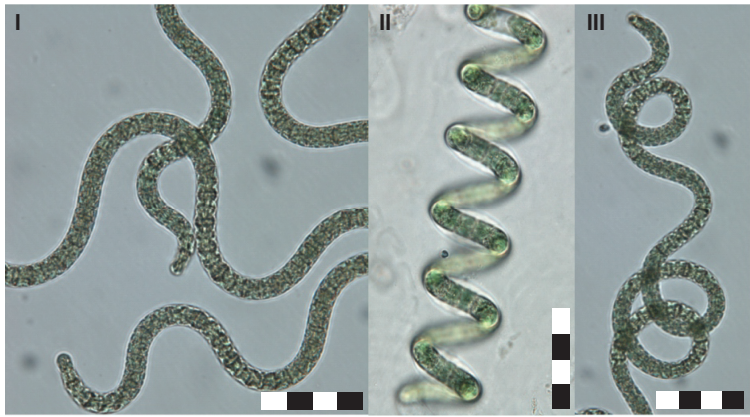

Figure 3.5I Arthrospira sp. with curved (I), coiled (II) or irregularly curved trichomes (III). Units in scale bars correspond to $5 \mu \mathrm{m}$. For origin of individual photographs, see the end of this chapter.

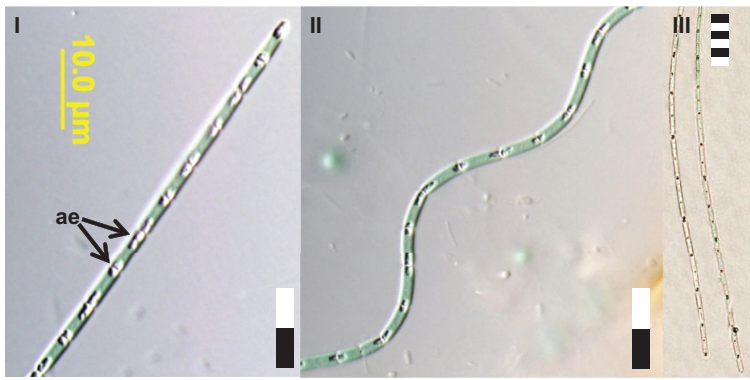

Figure 3.5J Limnothrix sp. Aerotopes (ae) typically at cell poles. Units in scale bars correspond to $5 \mu \mathrm{m}$. For origin of individual photographs, see the end of this chapter.

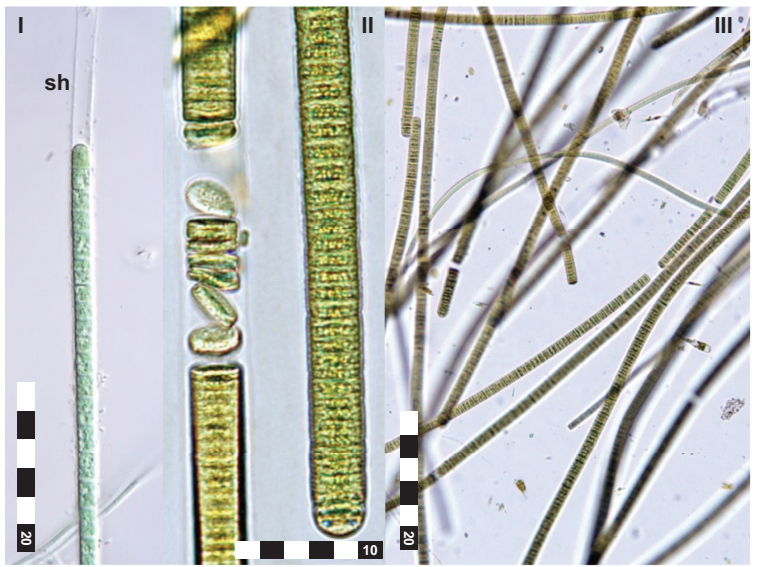

Figure 3.5K Lyngbya sp. Cells are enveloped in a sheath (sh) that can be partly empty. Units in scale bars correspond to $5 \mu \mathrm{m}$ if not indicated otherwise. For origin of individual photographs, see the end of this chapter. 


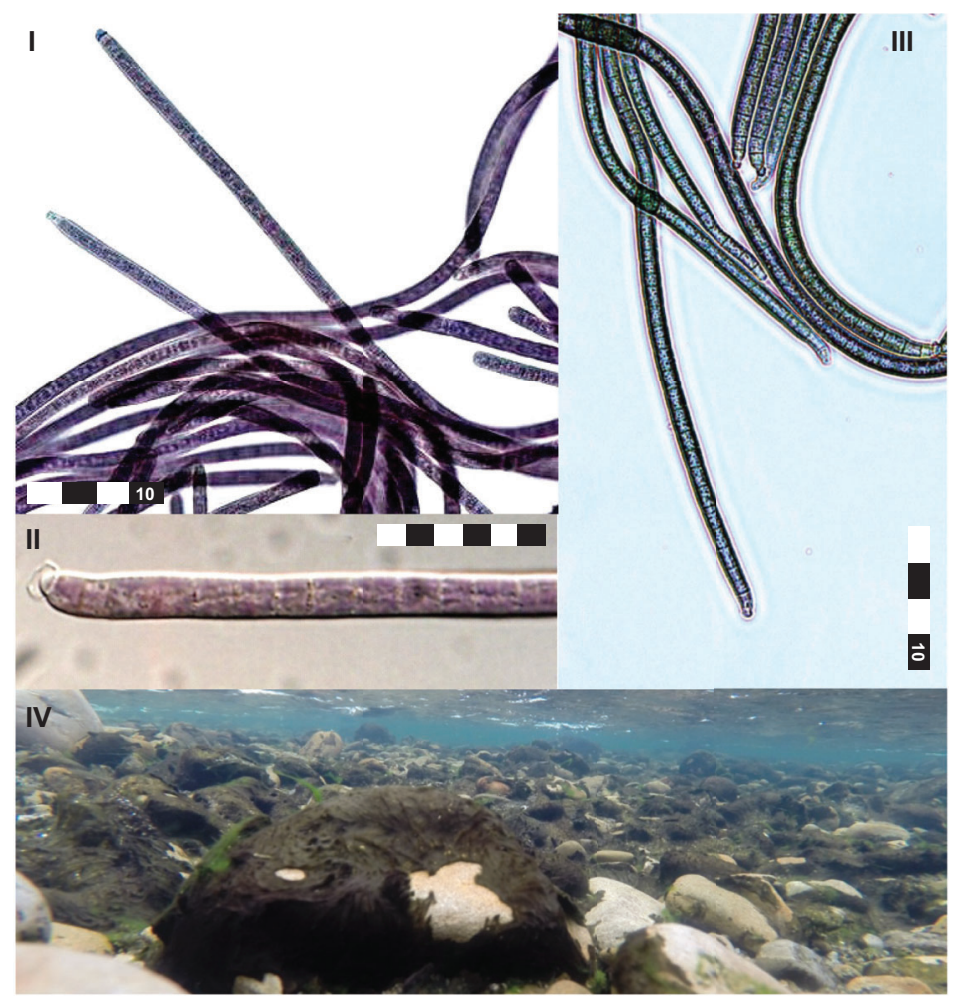

Figure 3.5L Microcoleus/Phormidium sp. Trichomes without sheath and typically pointed terminal cells (I-III). In natural habitats, Microcoleus (Phormidium) autumnalis can form dense mats on hard substrates covering large parts of stream beds (IV). Units in scale bars correspond to $5 \mu \mathrm{m}$ if not indicated otherwise. For origin of individual photographs, see the end of this chapter.

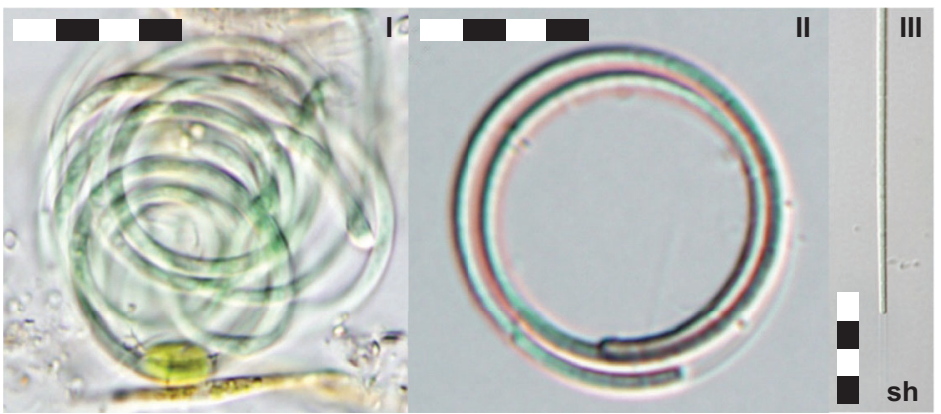

Figure 3.5M Planktolyngbya sp. Narrow trichomes in which individual cells can often not be distinguished, surrounded by a fine sheath (sh). Units in scale bars correspond to $5 \mu \mathrm{m}$. For origin of individual photographs, see the end of this chapter. 


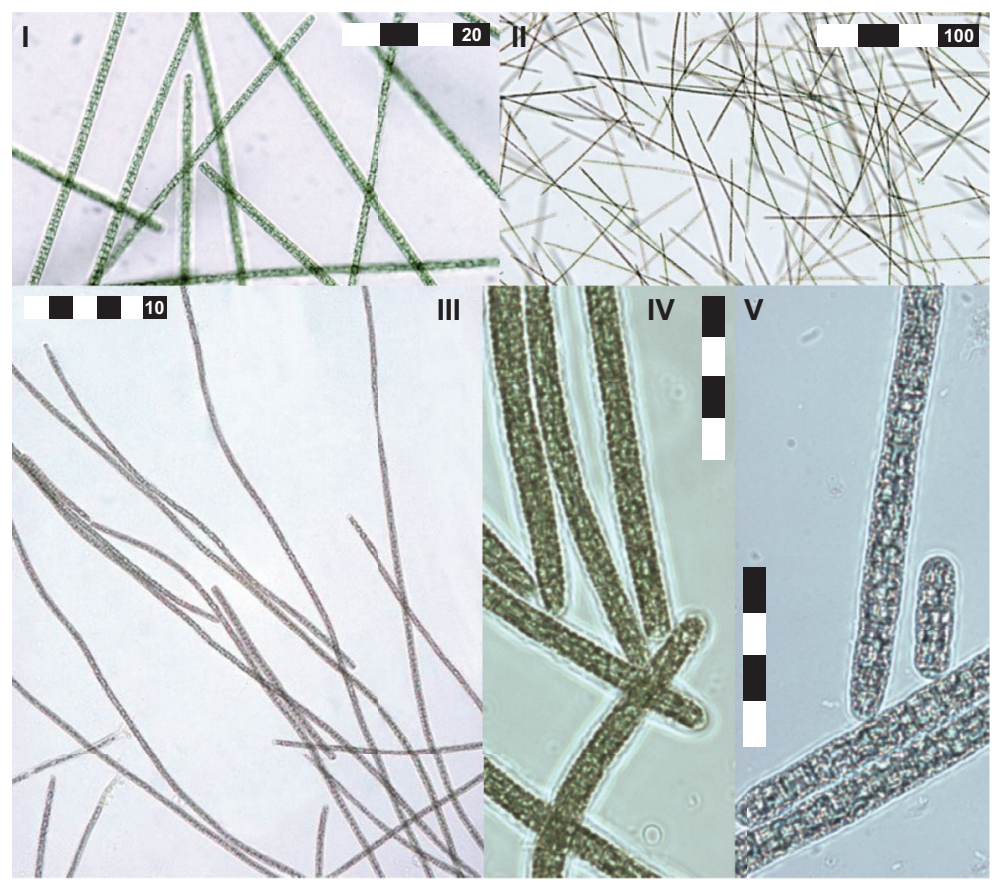

Figure 3.5N Planktothrix sp. Green pigmented P. agardhii (I, II, IV) with straight trichomes and many aerotopes. Red-pigmented $P$. rubescens (III, V) with wider and generally longer, slightly bent trichomes. Units in scale bars correspond to $5 \mu \mathrm{m}$ if not indicated otherwise. For origin of individual photographs, see the end of this chapter.

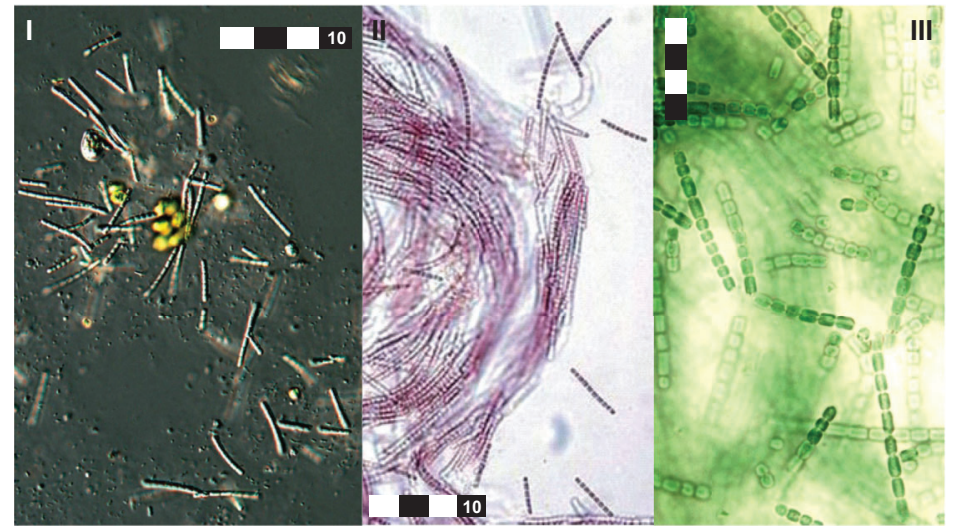

Figure 3.50 Pseudanabaena sp. Short trichomes associated with other phytoplankton (I). Red (II)- and green (III)-pigmented strains in culture, forming mats of long trichomes. Units in scale bars correspond to $5 \mu \mathrm{m}$ if not indicated otherwise. For origin of individual photographs, see the end of this chapter. 


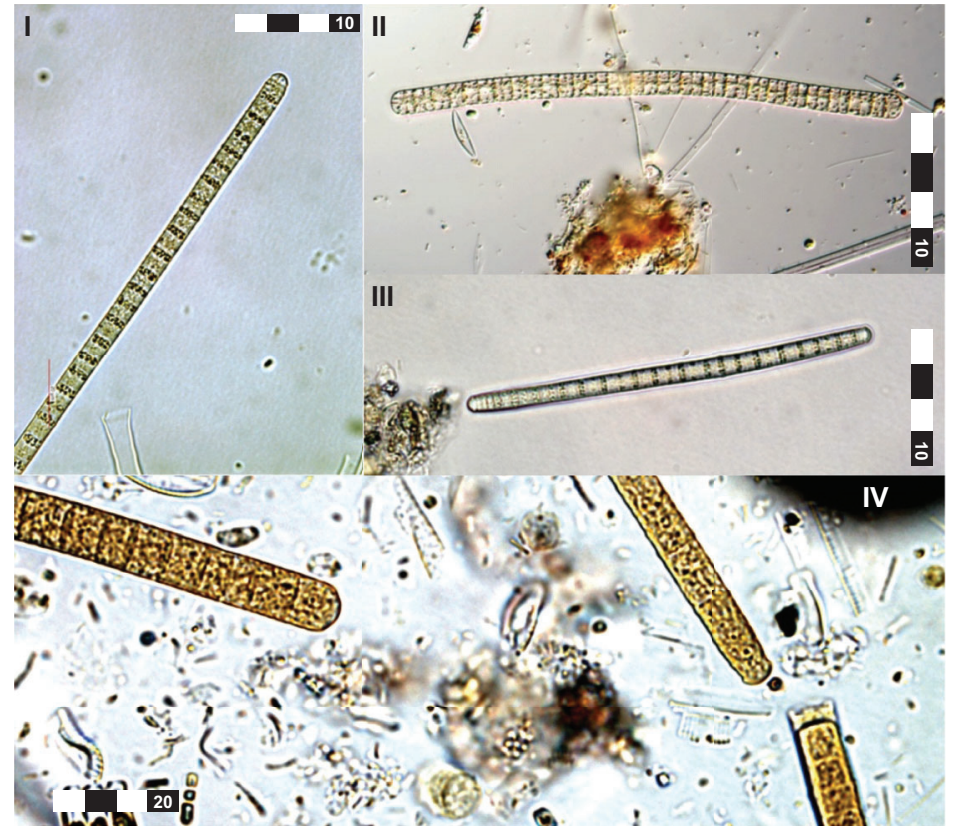

Figure 3.5P Tychonema sp. with partly hyaline cells (I-III). Typically, granulae accumulate at the cell walls. IV: Fragments of trichomes in a periphytic sample. Units in scale bars correspond to 10 or $20 \mu \mathrm{m}$ as indicated. For origin of individual photographs, see the end of this chapter.

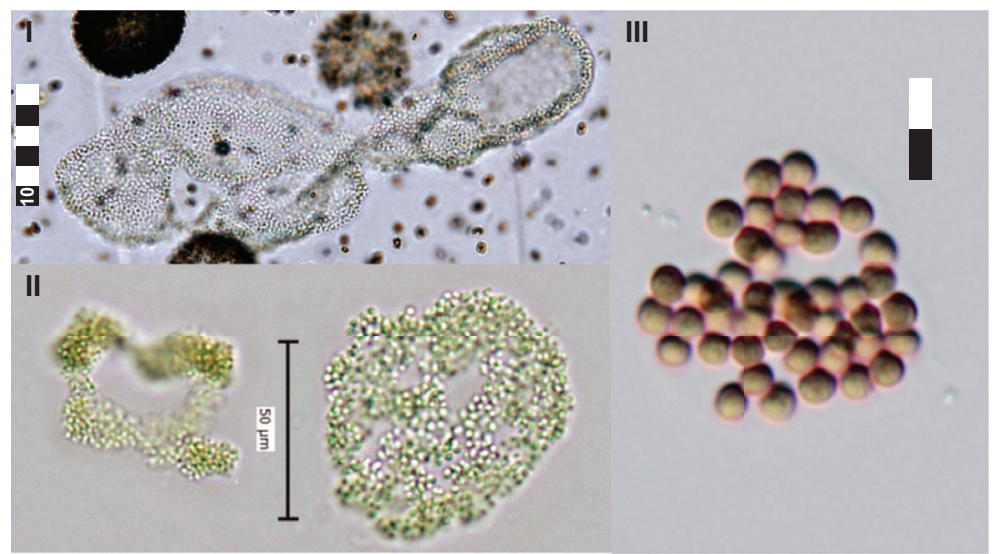

Figure 3.5Q Aphanocapsa sp. with small cells without aerotopes. In (I), cells and colonies of Microcystis sp. are shown for comparison. Units in scale bars correspond to $5 \mu \mathrm{m}$ if not indicated otherwise. For origin of individual photographs, see the end of this chapter. 


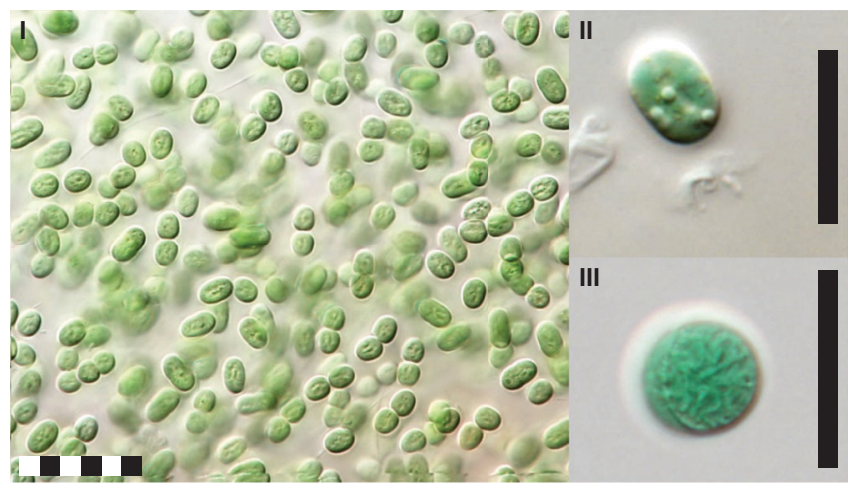

Figure 3.5R Aphanocapsa sp. (I), Synechococcus sp. (II) and Synechocystis sp. (III) with small cells without aerotopes. Units in scale bars correspond to $5 \mu \mathrm{m}$. For origin of individual photographs, see the end of this chapter.

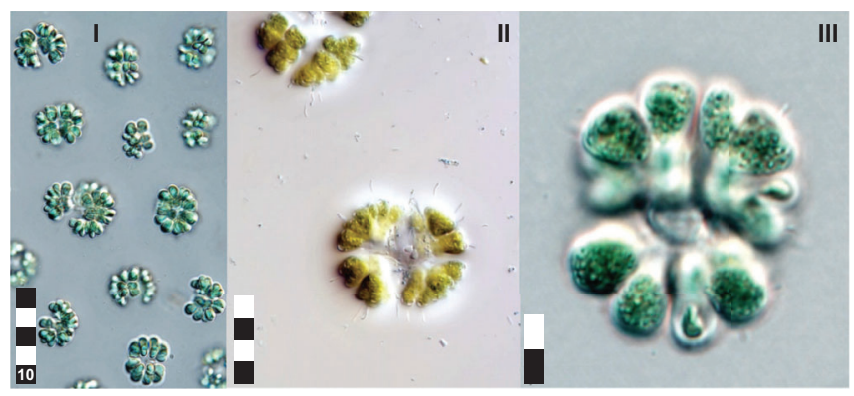

Figure 3.5S Gomphosphaeria sp. Small colonies of a few cells arranged radially. Units in scale bars correspond to $5 \mu \mathrm{m}$ if not indicated otherwise. For origin of individual photographs, see the end of this chapter.

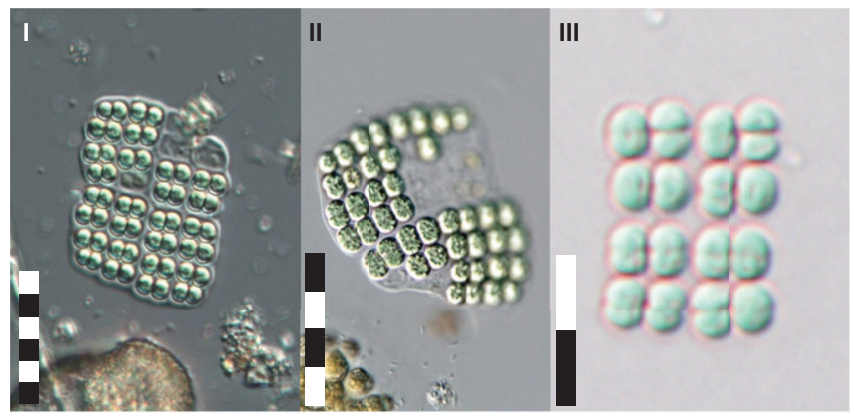

Figure 3.5T Merismopedia sp. with highly regular arrangement of cells in flat colonies. Unitsinscalebarscorrespond to $5 \mu \mathrm{m}$. Fororigin ofindividual photographs, seethe end of this chapter. 


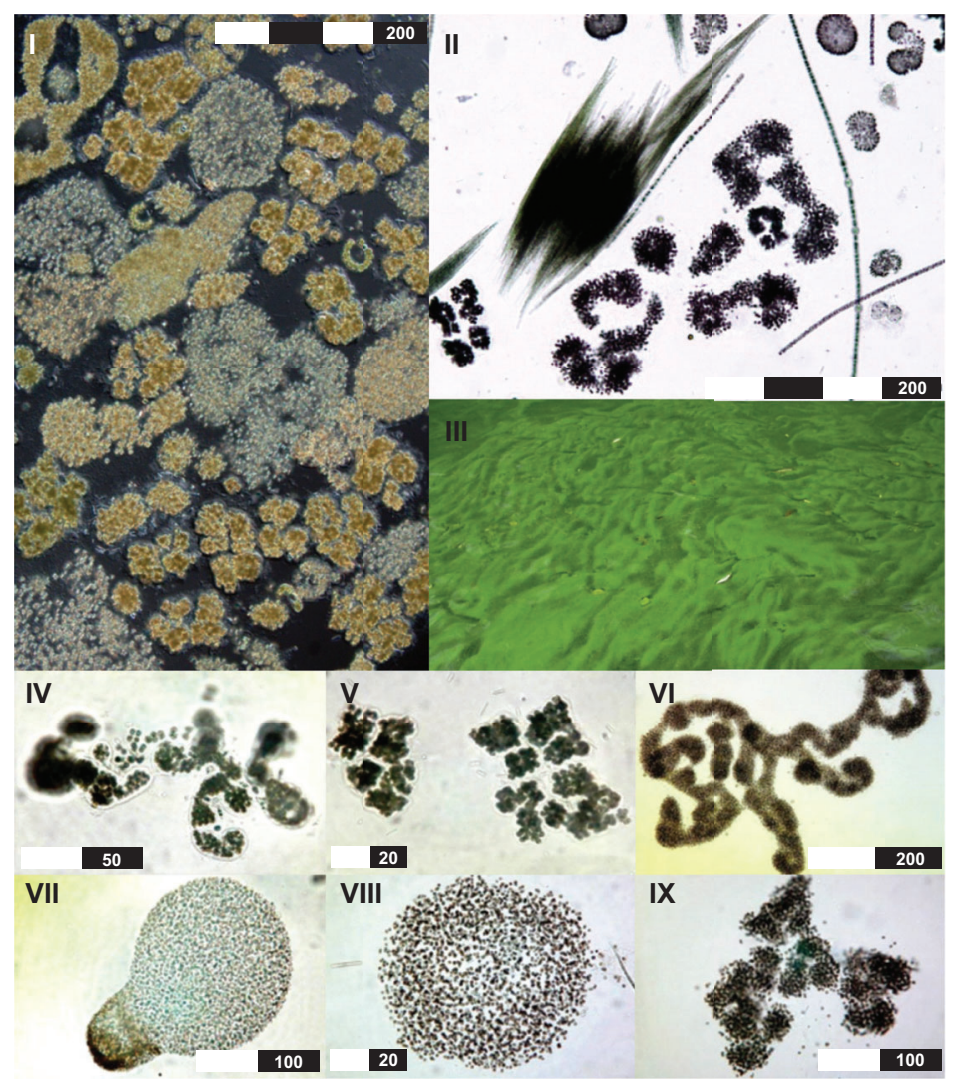

Figure 3.5U Microcystis sp. (I) natural sample comprising multiple Microcystis form species; (II) typical plankton community consisting of Aphanizomenon flosaquae fascicles, Microcystis colonies and Dolichospermum sp. trichomes; (III) Microcystis sp. surface bloom; IV-IX colonies of form species $M$. wesenbergii (IV), $M$. viridis (V), M. aeruginosa (VI), M. flosaquae (VII), M. ichtyoblabe (VIII) and $M$. novacekii (IX); note that the latter five form species have been proposed to be unified as M. aeruginosa based on molecular data (Otsuka et al., 200I). For ambiguities of Microcystis taxonomy, see also Box 3.I. Units in scale bars as indicated. For origin of individual photographs, see the end of this chapter.

In the following, abbreviations of genera differ occasionally from the general convention to use the initial letter to abbreviate a genus. This is done to avoid confusion, in particular if species epithets are identical. For example, Aphanizomenon flosaquae and Anabaena flosaquae are abbreviated as Aph. flosaquae and Ana. flosaquae, respectively (with the latter referred to as Dolichospermum flosaquae in the more recent literature). Note that the spelling of species epithets such as 'flos-aquae' has been chenged to nonhyphenated spelling 'flosaquae' in accordance with the International Code of Nomenclature for algae, fungi, and plants (Artcile 60.11; Turland et al., 2018). 
The full taxonomic name includes names of those who described them, for example, 'Anabaena Bory ex Bornet et Flahault'. The following section includes these for clarity.

\subsection{Filamentous forms with heterocytes}

These taxa correspond to subsection 4 in Table 3.2 or "Nostocales" and form filaments (trichomes) with heterocytes and akinetes.

Anabaena Bory ex Bornet et Flahault

\section{Morphological description}

The morphology of Anabaena sensu stricto largely corresponds to that of Dolichospermum except for the consistent lack of aerotopes (Figure 3.5A).

\section{Taxonomic background}

The genus Anabaena underwent several revisions in recent years in the course of which several new genera were proposed (see Table 3.2). Anabaena sensu stricto now comprises a monophyletic cluster with several species.

\section{Ecology and distribution}

Species of Anabaena sensu stricto are primarily benthic or epiphytic but rarely planktonic.

\section{Anabaenopsis Miller}

\section{Morphological description}

Free-floating trichomes, solitary or forming small microscopic clusters. Trichomes straight, arcuated or coiled screw-like, usually not embedded in sheaths, but sometimes with a fine sheath. Vegetative cells cylindrical or barrel-shaped, shorter than wide or up to several times longer than wide, pale blue-green, with obligatory or facultative aerotopes, without (rarely) or with constrictions at the cross-walls. Heterocytes develop intercalary in pairs with certain distances from each other. As trichomes often disintegrate after heterocyte maturation between adjacent heterocytes, this typically results in short trichomes with terminal heterocytes. Oval, cylindrical or spherical akinetes develop intercalary, normally distant from heterocytes, but exceptionally adjacent to them. Akinetes generally develop solitary or in pairs, rarely arranged in series with up to five in a row (Figure 3.5B).

\section{Taxonomic background}

The genus is clearly defined phenotypically and has been confirmed by molecular analyses. Some species have been transferred to the genera (Cylindrospermopsis (now Raphidiopsis) and Cylindrospermum as they 
share a number of characteristics. More details are found in Komárek \& Anagnostidis (1989).

\section{Ecology and distribution}

All species are planktonic and primarily found in mesotrophic to eutrophic waters, either inland or coastal, with alkaline or slightly saline conditions. Distributed mainly in tropical and subtropical regions but also during summer in temperate zones.

\section{Aphanizomenon Morren ex Bornet et Flahault}

\section{Morphological description}

Trichomes straight or slightly bent and only slightly narrowing towards the end, generally without sheaths, but sometimes with a very fine sheath. In some species, trichomes tend to form fascicules, that is, macroscopically visible aggregates of multiple trichomes. Vegetative cells cylindrical or barrel-shaped (from 2 to $5 \mu \mathrm{m}$ in diameter) with variable length/width, often slightly constricted at the cross-wall. Cells contain aerotopes that are distributed evenly in the cells. Terminal cells larger than cells in the trichome, cylindrical with rounded ends or flattened, sometimes with hyaline (transparent) content. Generally, one heterocyte is placed intercalary (i.e., surrounded by vegetative cells) in individual trichomes, rarely 2-4 heterocytes per trichome. Heterocytes cylindrical, spherical or ellipsoidal. The akinetes develop adjacently from heterocyte (paraheterocytic, sometimes distant) forming a subsymmetric trichome. Akinetes often much larger than vegetative cells and are cylindrical, intercalary and solitary (rarely in pairs). Single trichomes of Aphanizomenon flosaquae without heterocytes are morphologically very similar to trichomes of Planktothrix agardhii (Figure 3.5C).

\section{Taxonomic background}

The traditional genus Aphanizomenon was recently restricted to a cluster of nine morphospecies (A. flosaquae, A. gracile, A. klebahnii, A. yezoense, A. paraflexuosum, A. flexuosum, A. slovenicum, A. platense and $A$. bungaricum) based on polyphasic analyses, while other morphotypes formerly placed in the genus were placed in other genera (Cuspidothrix, Sphaerospermopsis and Chrysosporum; (Rajaniemi et al., 2005a; Rajaniemi et al., 2005b; Komárek, 2013)). The main feature that separates these genera from Aphanizomenon sensu stricto is that Aphanizomenon spp. are able to form parallel fascicules that can reach macroscopic size of several millimetres visible as green, needle-like particles (Komárek, 2013). Further, the subsymmetric filaments are cylindrical, elongated with (almost) hyaline (i.e., transparent) terminal cells. Terminal cells rounded but without distinctly narrowed ends; that are typical for the proposed new genera. For a 
review of Aphanizomenon and related genera and their toxigenicity, see Cirés \& Ballot (2016).

\section{Ecology and distribution}

Aphanizomenon generally dominate eutrophic, stagnant waters, with low available nitrogen and thermal stratification. A. gracile is typically found in shallow lakes and reservoirs (Cirés et al., 2017). A. flosaquae, the most common species of the genus, occurs mainly in temperate zones. Other species occur only in isolated areas, but no tropical Aphanizomenon species are registered.

\section{Chrysosporum Zapomělová et al., 2012}

\section{Morphological description}

Solitary, straight or slightly bent trichomes with clear constrictions at the cell walls. Vegetative cells vary from nearly cylindrical to barrel-shaped or ellipsoidal. Terminal cells rounded and slightly pointed and partially hyaline (transparent). Solitary and cylindrical heterocytes formed intercalary (i.e., surrounded by vegetative cells). Akinetes characteristically oval with distinct granular contents, and distant from heterocytes, often situated nearly equidistant between two heterocytes (Figure 3.5D).

\section{Taxonomic background}

Only two species to date: Chrysosporum ovalisporum that has been renamed from Aphanizomenon ovalisporum and Chrysosporum bergii from Anabaena bergii (Zapomělová et al., 2012).

\section{Ecology and distribution}

Only limited data on the distribution of both species is available, indicating that these species may occur primarily in temperate to subtropical climates (Cirés \& Ballot, 2016).

\section{Cuspidothrix Rajaniemi et al.}

\section{Morphological description}

Solitary and free-floating trichomes forming heterocytes. Trichomes straight or coiled and characteristically clearly narrowed towards the ends. Cells slightly constricted or nonconstricted at the cross-walls, up to $6 \mu \mathrm{m}$ wide. Vegetative cells cylindrical with facultative aerotopes, generally much longer than wide. Typical apical (terminal) cells elongated up to several tens of $\mu \mathrm{m}$, attenuated and acuminate, and mainly hyaline (i.e., transparent). Heterocytes appear only intercalary (i.e., surrounded by vegetative cells), always solitary, cylindrical or elliptical. Akinetes elongated, more or less cylindrical intercalary, solitary or rarely in pairs, close or at a short distance to heterocytes. Trichomes subsymmetric with 
paraheterocytic akinetes situated on both sides or slightly distant from heterocytes (Figure 3.5E).

\section{Taxonomic background}

Cuspidothrix issatschenkoi was renamed from A. issatschenkoi based on polyphasic analyses (Rajaniemi et al., 2005a). Other species in the genus have formerly been assigned to Aphanizomenon, for example, Cuspidothrix capricornii and Cuspidothrix elenkinii.

\section{Ecology and distribution}

These species are planktonic in mesotrophic to eutrophic stagnant waters. They are rarely found in running waters. They are also present from freshwater to oligohaline and brackish waters.

Raphidiopsis(Fritschet Rich) Aguilera et al., including Cylindrospermopsis Seenayya et Subba Raju

\section{Morphological description}

Aguilera et al. (2018) proposed to unify the genera Cylindrospermopsis and Raphidiopsis and to give preference to the latter respecting the principle of priority. Because the scientific community is increasingly accepting this revision, in this volume the genus Raphidiopsis refers to the combination of the former genera Cylindrospermopsis and Raphidiopsis. However, since the study of Aguilera et al. (2018) is restricted to only a limited number of species, the taxonomic opinion may change again in the future.

The genus Raphidiopsis comprises solitary, free-floating trichomes forming heterocytes, except for species of Rhaphidiopsis sensu Fritsch et Rich, for example R. mediterranea. Trichomes straight, bent or screw-like coiled, but in several species narrowed towards ends and without sheaths. The main characteristic is the terminal position of heterocytes, one or two at each end of the trichome (when not absent). Heterocytes ovoid, conical or drop-like. Trichomes subsymmetric, isopolar but heteropolar when only one heterocyte is present, generally without constrictions at crosswalls. Vegetative cells cylindrical or barrel-shaped, usually distinctly longer than wide, pale blue-green, yellowish or olive-green, facultatively with aerotopes. Terminal cells conical, blunt or sharply pointed. Ellipsoidal or cylindrical akinetes $(2-4 \times$ longer and about $2 \times$ wider than the vegetative cells) develop usually distant from heterocytes, rarely adjacent to apical heterocytes (Figure 3.5F).

\section{Taxonomic background}

At present, 18 (morpho)species have been described of which, Raphidiopsis (Cylindrospermopsis) raciborskii appears to be the most important one with respect to cyanotoxin production. 


\section{Ecology and distribution}

In eutrophic, turbid, warm and polymictic waters. In tropics, the appearance is often connected with nitrogen limitation of phytoplankton. All species are planktonic in lakes of the pantropical region except Raphidiopsis raciborskii that dispersed into the temperate region during the last 100150 years (Padisák et al., 2016) where it can form dense, suspended water blooms.

Dolichospermum (Ralfs ex Bornet \& Flahault) Wacklin, Hoffman et Komárek

\section{Morphological description}

Free-floating trichomes forming heterocytes, straight, slightly curved or flexuous, irregularly or more or less screw-like coiled. Solitary trichomes, rarely joined in irregular clusters (very rarely in fascicules). Trichomes not attenuated towards the ends, without sheaths, sometimes with fine diffluent mucilaginous envelope. Vegetative cells usually clearly constricted at the cross-walls and with many aerotopes distributed throughout the cells. Cylindrical trichomes are isopolar, metameric with respect to heterocytes. Apical cells morphologically similar to other vegetative cells in the filament. Heterocytes form intercalarly, solitary or exceptionally in pairs. They develop from vegetative cells in metameric position. Akinetes are elongated and wider than vegetative cells; they develop paraheterocytically, that is, connected with heterocytes, rarely aside heterocytes from both sides or (more commonly) separated from them by several cells, solitary or up to six in a row (Figure $3.5 \mathrm{G}$ ).

\section{Taxonomic background}

The species of the genus Dolichospermum have been recently separated from the genus Anabaena. The main criterion for separating these genera is the absence of aerotopes in Anabaena s. str., which is consistent with analyses of genomic sequences (Wacklin et al., 2009). Besides the known toxigenic species such as D. flosaquae or D. circinale, more than 30 species are given in Wacklin et al. (2009), however, without an individual taxonomic evaluation.

\section{Ecology and distribution}

All species planktonic in vegetative state, rarely associated with macrophytes (metaphytic). Dolichospermum is found in mesotrophic to eutrophic, both stratified and shallow lakes, generally with low nitrogen concentrations, where it can form blooms and surface scums. Several species are considered to be tropical. 


\section{Sphaerospermopsis Zapomělová et al.}

\section{Morphological description}

Solitary trichomes straight, slightly bent or coiled with constrictions at cell walls. Vegetative cells cylindrical- to barrel-shaped with slightly elongated but not pointed terminal cells, often resembling cells within the trichome. Cylindrical to ellipsoidal heterocytes formed solitary and intercalary (i.e., surrounded by vegetative cells). Akinetes characteristically nearly spherical or ellipsoidal and often occur in groups of two or three, but also singularly. Akinetes are frequently formed adjacently to heterocytes, sometimes on both sides. Fragmentation of trichomes at the akinetes yields trichomes with terminal akinetes (Figure $3.5 \mathrm{H}$ ).

\section{Taxonomic background}

Sphaerospermopsis includes species formerly belonging to Anabaena as well as Aphanizomenon (Zapomělová et al., 2011; Table 3.2).

\section{Ecology and distribution}

Sphaerospermopsis occurs primarily in temperate, subtropical and tropical shallow lakes.

\subsubsection{Filamentous forms without heterocytes and akinetes}

These taxa correspond to subsection 3 in Table 3.1 or "Oscillatoriales" and form filaments (trichomes) without heterocytes and akinetes. Following more recent taxonomic schemes, the genera Planktolyngbya and Pseudanabaena are placed in the order Synechococcales (Komárek, 2016b).

\section{Arthrospira Stitzenberger ex Gomont}

\section{Morphological description}

Solitary trichomes always without heterocytes, free floating or in mats covering hard substrate (microscopic or macroscopic). Trichomes more or less regularly coiled screw-like along their entire length. Generally without sheaths; however, if a sheath is present, it is colourless, tube-like with open ends enclosing single trichomes. Trichomes isopolar, 3-10 $\mu \mathrm{m}$ wide. Cells cylindrical, more or less isodiametric or shorter than wide, pale or bright blue-green or olive-green, in planktonic forms with aerotopes and in benthic forms without aerotopes. Not or only slightly constricted at the visible crosswalls. Trichomes not attenuated or only slightly attenuated towards the ends, with motility due to a rotational movement. Terminal cells widely rounded, usually with thickened outer cell walls or with calyptra (Figure 3.5I). 


\section{Taxonomic background}

Arthrospira may be confused with Spirulina; the main difference is that Arthrospira has clearly delimited and visible cells, while in Spirulina crosswalls are not clearly visible. Further, Arthrospira has wider cells, and the trichomes are coiled in wider spirals compared to Spirulina trichomes that are tightly coiled. Eight species of Arthrospira are described, of which A. platensis seems to be the most frequently occurring one. However, in many reports, a species assignment is not made. Nowicka-Krawczyk et al. (2019) proposed to rename A. fusiformis to be renamed to Limnospira fusiformis.

\section{Ecology and distribution}

Arthrospira is generally found in shallow, turbid environments primarily in tropical and subtropical climates, in brackish or saline (alkaline) waters but occasionally also in freshwater.

\section{Limnothrix Meffert}

\section{Morphological description}

Trichomes solitary, always without heterocytes, free floating, isopolar. Straight or slightly curved or coiled irregularly screw-like, isopolar, without sheath or with an only very fine, colourless sheath. Trichomes cylindrical and from 1 to $6 \mu \mathrm{m}$ wide, without or with reduced motility. Cells isodiametrical or longer than wide, unconstricted or slightly constricted at the cross-walls. Colour can range from pale blue-green to brown and orange. Aerotopes characteristically located close to the cross-walls. Apical cells are usually cylindrical, but sometimes conical (Figure 3.5J).

\section{Taxonomic background}

Most species of Limnothrix were originally placed in the genus Oscillatoria. The genus was amended by Meffert (1988) and confirmed by more recent studies (Suda et al., 2002; Komárek et al., 2014). The genus Limnothrix includes strains closely related to Pseudanabaena (Nishizawa et al., 2010) and is classified in the order Synechococcales by Komárek et al. (2014).

\section{Ecology and distribution}

Planktonic or tychoplanktonic, in fresh, mesotrophic to eutrophic, turbid and mixed waterbodies. Limnothrix redekei is distributed widely in the temperate zones but does not frequently form blooms.

Lyngbya Agardh ex Gomont, Moorea Engene et al., Microseira McGregor and Sendall and related taxa

\section{Morphological description}

Unbranched trichomes not constricted at cross-walls, enclosed in a firm sheath that is often protruding from trichomes. Cells short, cylindrical or, more often, coin-like (cell width $\gg$ cell length). Often strongly pigmented 
with a brown-green or blue-green colour, making cell walls difficult to recognise. Lyngbya/Moorea forms benthic mats on hard substrates or occurs epiphytic, forming macroscopic structures sometimes described as "mermaid's hair" (Figure 3.5K).

\section{Taxonomic background}

Two of the most studied species with respect to cyanotoxins are Lyngbya majuscula and L. wollei. Toxigenic strains of both species have been studied taxonomically and are proposed to be renamed: one cluster of $L$. majuscula is proposed to be renamed to Moorea producens (Engene et al., 2012) and a cluster of L. wollei to Microseira wollei (McGregor \& Sendall, 2015). Further new genera separated from the Lyngbya species complex are Okeania (Engene et al., 2013) and Dapis (Engene et al., 2018). More than 500 species of Lyngbya are listed in AlgaeBase, with descriptions of a large share dating from before 1950, that is, without support from molecular data. Expectedly, this group of mainly marine filamentous cyanobacteria forming macroscopic aggregates will be subject to taxonomic revision once molecular and polyphasic analyses are conducted systematically (Engene et al., 2010).

\section{Ecology and distribution}

L. majuscula (Moorea producens) occurs primarily in brackish or marine habitats in tropical and subtropical zones. L. (Microseira) wollei is found in rivers and streams in temperate to subtropical zones where it forms. Other species of Lyngbya sensu stricto are found mostly in freshwaters.

\section{Phormidium Kützing ex Gomont, Microcoleus Desmazières ex Gomont and related taxa}

\section{Morphological description}

Unbranched trichomes generally form fine or thick mats (microscopic to macroscopic) and are rarely solitary. Trichomes isopolar, straight, coiled or waved, usually $<10-12 \mu \mathrm{m}$ wide, facultatively with tube-like, firm, colourless sheaths with open ends. Vegetative cells cylindrical to slightly barrelshaped, more or less isodiametrical or slightly shorter or longer than wide, constricted or unconstricted at the cross-walls, generally without aerotopes but with refractive granules. Trichomes not attenuated at the ends, sometimes bent or twisted screw-like towards the ends, motile within and outside of sheaths (Figure 3.5L).

\section{Taxonomic background}

This genus comprises a large number of species ( $>400$; e.g., $P$. nigrum, $P$. autumnale, $P$. fragile), and the taxonomic status of many has been challenged (Palinska et al., 2011). As a consequence, a number of Phormidium species have been assigned to new genera, for example, Wilmottia (Strunecký et al., 2011), Oxynema (Chatchawan et al., 2012; Strunecký et al., 2014) or to 
existing genera such as Microcoleus (Phormidium) autumnalis (Strunecký et al., 2013) based on molecular analyses. Microcoleus anatoxicus has been reported to produce primarily dihydroanatoxin a (Conklin et al. 2020). For this reason, specimens of this taxon are often reported as Phormidium sp. and species assignment in elder publication may be no longer valid from a today's point of view. Phormidium may be confused with Geitlerinema, Lyngbya (Moorea, Microseira) and others.

\section{Ecology and distribution}

Epiphytic or epilithic in shallow rivers or streams but also in shallow areas in eutrophic standing waters. Due to the uncertain taxonomy and the resulting difficulties for unambiguous species determination, the knowledge on geographic distribution of individual Phormidium species is incomplete (Marquardt \& Palinska, 2007). Specimens of the genus were found in a variety of latitudes, including extreme cold environments (Strunecký et al., 2012).

\section{Planktolyngbya Anagnostidis et Komárek}

\section{Morphological description}

Trichomes without heterocytes, solitary, with thin, simple, colourless, but firm sheaths. Isopolar, cylindrical trichomes, narrow, up to $3 \mu \mathrm{m}$ wide, straight, waved or coiled, generally not narrowed to the ends. Slightly constricted or unconstricted at the cross-walls, and always immotile. Cylindrical cells usually longer than wide (rarely shorter than wide), without aerotopes, pale grey-blue, blue-green, yellowish or olive-green. Terminal cells rounded or narrowed-rounded without a calyptra (Figure $3.5 \mathrm{M}$ ).

\section{Taxonomic background}

The genus was separated from Lyngbya by Anagnostidis and Komárek (1988) and confirmed by polyphasic analysis (Komárek et al., 2014) who placed the genus to the order Synechococcales (family Leptolyngbyaceae).

\section{Ecology and distribution}

Planktonic species are typical in large, mesotrophic reservoirs. Some species are limited to tropical and warm areas of temperate zones, while several species are presumably nordic.

\section{Planktothrix Anagnostidis et Komárek}

\section{Morphological description}

Trichomes always solitary, free floating, more or less straight or slightly irregularly waved or curved. In culture, trichomes may form irregular 
clusters. Sheaths generally absent; if present, they are fine, colourless and diffluent. Trichomes isopolar, cylindrical, not constricted or slightly constricted at cross-walls. Length of trichomes up to $4 \mathrm{~mm}$, width 3-12 $\mu \mathrm{m}$. Immotile or sometimes slightly motile (trembling, gliding), slightly attenuated or not attenuated towards the ends, sometimes capitated or with terminal calyptra. Most species with prominent aerotopes take a large share of the cells' volume. Vegetative cells cylindrical or (rarely) slightly barrel-shaped, shorter than wide, up to \pm isodiametric or rarely little longer than wide (Figure $3.5 \mathrm{~N}$ ).

\section{Taxonomic background}

Planktothrix was originally placed in the genus Oscillatoria, from which it was separated due to ecological traits and the formation of large numbers of aerotopes (Anagnostidis \& Komárek, 1988).

Several species are described, of which Planktothrix agardhii and $P$. rubescens are the most relevant with respect to cyanotoxins. Other species (e.g., P. mougeotii, P. pseudagardhii and P. spiroides) are morphologically similar but have not been reported to form blooms. Some species produce only few aerotopes ( $P$. pancivesiculata, $P$. serta; Gaget et al., 2015a).

\section{Ecology and distribution}

Generally, planktonic and evenly distributed in the water column in nonstratified, shallow lakes (P. agardhii) or cumulated at the thermocline of deep, stratified lakes (P. rubescens or, more rarely, P. mougeotii), occasionally forming blooms. In the case of blooms of $P$. rubescens, these may accumulate at the metalimnion and not be visible at the surface (see Chapter 4). Both species tolerate low light intensities. The genus is widely distributed in temperate climates, but individual species may show more restricted distribution patterns.

\section{Pseudanabaena Lauterborn}

\section{Morphological description}

Trichomes without branching and without firm sheaths, sometimes with fine, colourless, diffluent envelopes. Trichomes solitary or agglomerated in very fine mucilaginous mats. Individual trichomes straight, slightly waved or bent, usually not very long, 0.8-3 $\mu \mathrm{m}$ wide, not attenuated at the ends, usually with slight constrictions at the distinct cross-walls. Cells cylindrical, usually longer than wide (sometimes barrel shaped or nearly spherical). The apical cell is cylindrical and rounded at the end or more or less conical up to bluntly or sharply pointed. Generally without aerotopes, but sometimes with aerotopes at the ends of cells. Trichomes may have motility (trembling). Pigmentation often reddish (Figure 3.5O). 


\section{Taxonomic background}

Pseudanabaena is closely related to Limnothrix (Acinas et al., 2009), and some authors refer to this as "Pseudanabaena/Limnothrix" group (e.g., Zwart et al., 2005). Both genera have been assigned to the order Synechococcales sensu (Komárek et al., 2014); these genera are close to single-cell forms such as Synechococcus sp.

\section{Ecology and distribution}

Mostly planktonic species, tychoplanktonic or benthic in oligotrophic, mesotrophic up to slightly eutrophic water reservoirs and turbid mixed waters. Short trichomes of Pseudanabaena endophytica can often be found attached to colonies of Microcystis.

\section{Tychonema Anagnostidis et Komárek}

\section{Morphological description}

Unbranched, cylindrical trichomes lack a visible sheath of 7-12 $\mu \mathrm{m}$ width not constricted at cross-walls. Cells generally slightly shorter than wide or isodiametrical and appear almost empty except for granulae at the crosswalls or the cell periphery. Trichomes mostly solitarily and lacking motility as observed in Geitlerinema or Phormidium (Figure 3.5P).

\section{Taxonomic background}

Tychonema is a currently recognised distinct genus within Oscillatoriales (Anagnostidis \& Komárek, 1988) and has been confirmed by polyphasic analyses (Suda et al., 2002). Four species are described, the distinction of which may be difficult (Tychonema bornetii, T. bourrellyi, T. decoloratum and T. tenue).

\section{Ecology and distribution}

As the name already indicates, Tychonema typically is tychoplanktonic: the trichomes are loosely attached to macrophytes or hard substrate but can be detached due to water movement and become planktonic.

Tychonema is primarily found in mesotrophic lakes of temperate zones where macrophyte stands exist, for example, in assemblages of water moss (Fastner et al., 2018). T. bourrellyi is considered as truly planktonic (Salmaso et al., 2016b).

\subsubsection{Colonial forms}

These taxa correspond to subsection 1 in Table 3.1 or "Chroococcales" and are unicellular with cells embedded in a common mucilage. Following more recent taxonomic schemes, the genera Aphanocapsa and Merismopedia are placed in the order Synechococcales (Komárek, 2016b). 


\section{Aphanocapsa Nägeli}

\section{Morphological description}

Cells form microscopic (sometimes macroscopic) more or less spherical or irregular colonies with irregularly, loosely or densely distributed cells. Mucilage fine and diffluent, generally colourless but macroscopically colonies appear as firm sheaths. Cells spherical from 1.5 to $6 \mu \mathrm{m}$ of diameter (hemispherical after division), without own mucilaginous envelopes, generally without aerotopes, sometimes with granular content. Cell division always in two perpendicular planes in successive generations. Some species are morphologically similar to Microcystis, except for the lack of aerotopes in Aphanocapsa (Figure 3.5Q).

\section{Taxonomic background}

It is suggested that planktonic species need revision as the relationship to other form genera like Microcystis is not clear.

\section{Ecology and distribution}

Periphytic, benthic or metaphytic in stagnant and running freshwater systems, usually with clear water, common in lakes. Often found in late summer in the epilimnion of oligotrophic, deep lakes. Registered worldwide, but several species are ecologically sharply limited and occur in geographically limited areas.

Similar small coccoid taxa are the colony-forming Aphanothece and single-celled Synechococcus and Synechocystis (Figure 3.5R).

\section{Gomphosphaeria Kützing}

\section{Morphological description}

Cells embedded in a mucilage forming spherical or irregularly oval colonies, sometimes composed of multiple subcolonies. Mucilage with gelatinous stalks that radiate from the centre of the colony to the periphery. The stalks are widened at the ends and envelope individual cells with a thin mucilage layer. Cells elongate $(6-12 \times 2-8 \mu \mathrm{m})$, radially oriented at the end of stalks. Pigmentation pale or bright blue-green, olive-green or red (Figure 3.5S).

\section{Taxonomic background}

At first sight, the genus can be confused with Snowella or Coelosphaerium; see taxonomic update in Komárek and Anagnostidis (1999).

\section{Ecology and distribution}

Generally, found in eutrophic to hypertrophic, small- to medium-sized lakes. 


\section{Merismopedia Meyen}

\section{Morphological description}

Free-floating microscopic colonies, square or rectangular with one layer of cells densely or loosely arranged in a single plane. Larger colonies may be contorted or composed of several subcolonies. Colonies of a few to several cells that divide in two alternating planes, forming groups of 4 or 16 cells that collectively form distinctive, flat colonies with hyaline (transparent), fine envelopes, some species with envelopes surrounding each cell. Cells spherical or elliptical (hemispherical after division), generally pale or bright blue-green content; in a few species in central parts of cells with refractive granulae or aerotopes (Figure 3.5T).

\section{Taxonomic background}

Some 20 morphospecies of Merismopedia are described, for example, M. glauca, M. punctata or M. elegans. In most ecological studies, only Merismopedia sp. is reported.

\section{Ecology and distribution}

Planktonic or metaphytic, usually in biotopes with submerged macrophyte vegetation. Temperate habitats: deep and shallow, oligotrophic to eutrophic, medium to large lakes. Common in the epilimnion of mesotrophic lakes in summer.

Cosmopolitan distribution, but several species have clearly ecologically and geographically limited areas of distribution.

\section{Microcystis Kützing ex Lemmermann}

\section{Morphological description}

Free-floating microscopic or macroscopic colonies, spherical, oval or elongated, in several species clathrate. A large number of species have been described based mainly on cell size and colony morphology. The latter is, however, not available in cultured strains that generally grow as single cells or atypical colonies (Otsuka et al., 2000). The same is true for samples fixed with Lugol's solution in which colonies disintegrate to small clusters or single cells, allowing a differentiation only by cell size. In some species, colonies are composed of subcolonies or multiple more or less separated clusters of cells. All cells densely or sparsely arranged in a common mucilage with the density of cells highly variable in particular species. Mucilage fine, colourless, diffluent or distinct and delimited (e.g., Microcystis wesenbergii). Gelatinous envelopes around individual cells are never present. Cells spherical or hemispherical shortly after division, ranging from 2 to $7 \mu \mathrm{m}$ in diameter or slightly elongated, with many, irregularly arranged aerotopes. Differentiation of morphospecies in samples of natural populations is often uncertain as many colonies show characteristics of more than one morphospecies (Figure 3.5U). 


\section{Taxonomic background}

The number of described morphospecies varies depending on the reference source chosen (see Box 3.1). Due to phenotypic variability, the status of individual morphospecies and their relationships is largely unclear. The genus Microcystis is one of the few cyanobacterial genera that underwent systematic taxonomic revision based on molecular data. As a result, based on genomic DNA homologies, Otsuka et al. (2001) proposed to unify the species $M$. aeruginosa, M. ichthyoblabe, M. novacekii, $M$. viridis and M. wesenbergii in a single species. This is also supported by Harke et al. (2016), but nonetheless, this proposal has not been validated, primarily for formal reasons (Oren \& Ventura, 2017).

A particular morphotype occurring in tropical waters has been described as Radiocystis. This genus is characterised by cells more or less arranged in radial series protruding from the centre embedded in a mucilage also showing radial structures (Komárek \& Komárková-Legnerová, 1993). Genomic sequences such as $16 \mathrm{~S}$ rRNA or phycocyanin operon are, however, identical to those of Microcystis (Vieira et al., 2003). Similarly, Sphaerocarvum sp. has been split from the genus Microcystis based on a particular colony morphology in situ (Azevedo \& Sant'Anna, 2003), but has genomic sequences identical to Microcystis (Rigonato et al., 2018).

\section{Ecology and distribution}

Planktonic, in mesotrophic to eutrophic standing waters that are at least temporally stratified, preferably in shallow or medium depth lakes. Mostly absent or restricted to the shallow basins or to the littoral region in deep, stratified lakes where they can, however, form large blooms like in the North American great lakes. Microcystis frequently forms blooms in eutrophic systems, and under conditions of stable thermal stratification, it can form surface blooms and massive scums. Colonies can sink to the bottom and overwinter in the sediment.

Many species with a cosmopolitan distribution, except in subpolar regions but several taxa are restricted geographically due to ecological preferences (van Gremberghe et al., 2011; Harke et al., 2016).

\section{PICTURE CREDITS}

Microscopic photographs for Figure 3.5A-U were kindly provided as listed here. All contributions are highly appreciated. Andreas Ballot: 3.5C-II, 3.5DI, 3.5D-II, 3.5D-III, 3.5F-V, 3.5F-VI, 3.5G-II, 3.5G-IV, 3.5H-I, 3.5H-III, 3.5I-I, 3.5I-II, 3.5I-III. Barry H. Rosen, Florida Gulf Coast University; Fort Myers (Fl), USA (brosen@fgcu.edu): 3.5A-II, 3.5C-V, 3.5E-II, 3.5F-IV, 3.5GIII, 3.5J-I, 3.5J-II, 3.5K-I, 3.5L-II, 3.5M-I, 3.5M-II, 3.5M-III, 3.5P-II, 3.5QIII, 3.5R-I, 3.5R-II, 3.5R-III, 3.5S-II, 3.5S-III, 3.5T-III. Anja Hoffmann, 
Landeslabor Berlin-Brandenburg, Inst. für Lebensmittel, Arzneimittel, Tierseuchen und Umwelt -, Berlin, Germany (Anja.Hoffmann@LandeslaborBBB.de): 3.5P-I, 3.5P-III, 3.5P-IV. Hydrobiology Area, Central Laboratory, Obras Sanitarias del Estado (OSE), Montevideo, Uruguay: 3.5B-I, 3.5B-III, 3.5E-III, 3.5F-II. Martin Welker: 3.5C-I, 3.5F-III, 3.5L-I, 3.5L-III, 3.5NIII, 3.5 N-IV, 3.5N-V, 3.5O-II, 3.5O-III, 3.5U-III, 3.5U-IV, 3.5U-V, 3.5UVI, 3.5U-VII, 3.5U-VIII, 3.5U-IX. Petr Znachor, Institute of Hydrobiology, Biology Centre CAS, České Budějovice, Czech Republic (znachy@gmail.com; www.fytoplankton.cz): 3.5C-VII, 3.5D-IV, 3.5F-I, 3.5G-I, 3.5H-II, 3.5O-I, 3.5S-I, 3.5T-I, 3.5T-II, 3.5U-I. Radovan Kopp, Mendelova univerzita v Brně, Brno, Czech Republic (Fcela@seznam.cz): 3.5A-I, 3.5B-II, 3.5C-III, 3.5CIV, 3.5C-VI, 3.5C-VIII, 3.5E-I, 3.5J-III, 3.5K-II, 3.5K-III, 3.5N-I, 3.5N-II, 3.5Q-I, 3.5Q-II, 3.5U-II. Susanna A. Wood, Cawthron Institute, Nelson, New Zealand (Susie.Wood@cawthron.org.nz): 3.5L-IV.

\section{REFERENCES}

Acinas SG, Haverkamp THA, Huisman J, Stal LJ (2009). Phenotypic and genetic diversification of Pseudanabaena spp. (cyanobacteria). ISME J. 3:31-46.

Adams DG, Duggan PS (1999). Heterocyst and akinete differentiation in cyanobacteria. New Phytol. 144:3-33.

Aguilera A, Gómez EB, Kaštovský J, Echenique RO, Salerno GL (2018). The polyphasic analysis of two native Raphidiopsis isolates supports the unification of the genera Raphidiopsis and Cylindrospermopsis (Nostocales, Cyanobacteria). Phycologia. 57:130-146.

Anagnostidis K, Komárek J (1985). Modern approach to the classification system of Cyanophytes. 1-Introduction. Arch Hydrobiol Algol Stud. 38-39:291-302.

Anagnostidis K, Komárek J (1988). Modern approach to the classification system of Cyanophytes 3-Oscillatoriales. Arch Hydrobiol Algol Stud. 80 (50-53):327-472.

Azevedo TMP, Sant'Anna CL (2003). Sphaerocavum, a new genus of planktic Cyanobacteria from continental water bodies in Brazil. Algol Stud. 109:79-92.

Berman-Frank I, Lundgren P, Falkowski P (2003). Nitrogen fixation and photosynthetic oxygen evolution in cyanobacteria. Res Microbiol. 154:157-164.

Bothe H, Schmitz O, Yates MG, Newton WE (2010). Nitrogen fixation and hydrogen metabolism in cyanobacteria. Microbiol Mol Biol Rev. 74:529-551.

Burja AM, Banaigs B, Abou-Mansour E, Burgess JG, Wright PC (2001). Marine cyanobacteria-a prolific source of natural products. Tetrahedron. 57:9347-9377.

Castenholz RW, Wilmotte A, Herdman M, Rippka R, Waterbury JB, Iteman I et al. (2001). Phylum BX. Cyanobacteria. In: Garrity G, Boone DR, Castenholz DW, editors: Bergey's Manual ${ }^{\circledR}$ of systematic bacteriology. New York: Springer:473-599.

Cavalier-Smith T (2002). The neomuran origin of archaebacteria, the negibecterial root of the universal tree and bacterial megaclassification. Int J Syst Evol Microbiol. 52:7-76.

Chatchawan T, Komárek J, Strunecký O, Šmarda J, Peerapornpisal Y (2012). Oxynema, a new genus separated from the genus Phormidium (Cyanophyta). Cryptogam Algol. 33:41-60. 
Cirés S, Ballot A (2016). A review of the phylogeny, ecology and toxin production of bloom-forming Aphanizomenon spp. and related species within the Nostocales (cyanobacteria). Harmful Algae. 54:21-43.

Cirés S, Delgado A, González-Pleiter M, Quesada A (2017). Temperature influences the production and transport of saxitoxin and the expression of sxt genes in the cyanobacterium Aphanizomenon gracile. Toxins. 9:322.

Conklin KY, Stancheva R, Otten TG, Fadness R, Boyer GL, Read B et al. (2020) Molecular and morphological characterization of a novel dihydroanatoxin-a producing Microcoleus species (cyanobacteria) from the Russian River, California, USA. Harmful Algae 93:101767.

De Philippis R, Vincenzini M (1998). Exocellular polysaccharides from cyanobacteria and their possible applications. FEMS Microbiol Rev. 22:151-175.

Dillon JG, Castenholz RW (1999). Scytonemin, a cyanobacterial sheath pigment, protects against UVC radiation: implications for early photosynthetic life. J Phycol. 35:673-681.

Dvořák P, Casamatta DA, Hašler P, Jahodářová E, Norwich AR, Poulíčková A (2017). Diversity of the cyanobacteria. In: Hallenbeck P, editor: Modern topics in the phototrophic prokaryotes. Cham: Springer.

Dvořák P, Jahodářová E, Casamatta DA, Hašler P, Poulíčková A (2018). Difference without distinction? Gaps in cyanobacterial systematics; when more is just too much. Fottea. 18:130-136.

Engene N, Coates RC, Gerwick WH (2010). 16S rRNA Gene heterogeneity in the filamentous marine cyanobacterial genus Lyngbya. J Phycol. 46:591-601.

Engene N, Paul VJ, Byrum T, Gerwick WH, Thor A, Ellisman MH (2013). Five chemically rich species of tropical marine cyanobacteria of the genus Okeania gen. nov.(Oscillatoriales, Cyanoprokaryota). J Phycol. 49:1095-1106.

Engene N, Rottacker EC, Kaštovský J, Byrum T, Choi H, Ellisman $\mathrm{MH}$ et al. (2012). Moorea producens gen. nov., sp. nov. and Moorea bouillonii comb. nov., tropical marine cyanobacteria rich in bioactive secondary metabolites. Int J Syst Evol Microbiol. 62:1171-1178.

Engene N, Tronholm A, Paul VJ (2018). Uncovering cryptic diversity of Lyngbya: the new tropical marine cyanobacterial genus Dapis (Oscillatoriales). J Phycol. 54:435-446.

Fastner J, Beulker C, Geiser B, Hoffmann A, Kröger R, Teske K et al. (2018). Fatal neurotoxicosis in dogs associated with tychoplanktic, anatoxin-a producing Tychonema sp. in mesotrophic Lake Tegel, Berlin. Toxins. 10:60.

Flombaum P, Gallegos JL, Gordillo RA, Rincón J, Zabala LL, Jiao N et al. (2013). Present and future global distributions of the marine Cyanobacteria Prochlorococcus and Synechococcus. Proc Natl Acad SciUSA. 110:9824-9829.

Frigaard N-U, Larsen KL, Cox RP (1996). Spectrochromatography of photosynthetic pigments as a fingerprinting technique for microbial phototrophs. FEMS Microbiol Lett. 20:69-77.

Gaget V, Welker M, Rippka R, de Marsac NT (2015a). A polyphasic approach leading to the revision of the genus Planktothrix (Cyanobacteria) and its type species, P. agardhii, and proposal for integrating the emended valid botanical taxa, as well as three new species, Planktothrix paucivesiculata sp. nov., Planktothrix tepida sp. nov., and Planktothrix serta sp. nov., as genus and species names with nomenclatural standing under the ICNP. Syst Appl Microbiol. 38:141-158. 
Gaget V, Welker M, Rippka R, Tandeau de Marsac N (2015b). Response to: Comments on: "A polyphasic approach leading to the revision of the genus Planktothrix (Cyanobacteria) and its type species, P. agardhii, and proposavl for integrating the emended valid botanical taxa, as well as three new species, Planktothrix paucivesiculata sp. nov.(ICNP), Planktothrix tepida sp. nov.(ICNP), and Planktothrix serta sp. nov.(ICNP), as genus and species names with nomenclature standing under the ICNP”. Syst Appl Microbiol. 38:368-370.

Garcia-Pichel F, Lombard J, Soule T, Dunaj S, Wu SH, Wojciechowski MF (2019). Timing the evolutionary advent of cyanobacteria and the later Great Oxidation Event using gene phylogenies of a sunscreen. mBio. 10:e0561-00519.

Geitler L (1932). Cyanophyceae. In: Rabenhorst L, editor: Kryptogamenflora von Deutschland. Leipzig: Akad. Verlagsges:673-1196.

Gerwick WH, Tan LT, Sitachitta N (2001). Nitrogen-containing metabolites from marine cyanobacteria. Alkaloids Chem Biol. 57:75-184.

Gugger MF, Hoffmann L (2004). Polyphyly of true branching cyanobacteria (stigonematales). Int J Syst Evol Microbiol. 54:349-357.

Guiry MD, Guiry GM (2019). AlgaeBase. Galway: National University of Ireland.

Hamilton TL, Bryant DA, Macalady JL (2016). The role of biology in planetary evolution: cyanobacterial primary production in low-oxygen Proterozoic oceans. Environ Microbiol. 18:325-340.

Harke MJ, Steffen MM, Gobler CJ, Otten TG, Wilhelm SW, Wood SA et al. (2016). A review of the global ecology, genomics, and biogeography of the toxic cyanobacterium, Microcystis spp. Harmful Algae. 54:4-20.

Hauer T, Komárek J (2019). CyanoDB.cz 2.0- On-line database of cyanobacterial genera. České Budějovice: University of South Bohemia \& Academy of Sciences of the Czech Republic.

Hoffmann L, Komárek J, Kaštovský J (2005). System of cyanoprokaryotes (cyanobacteria)-state in 2004. Algol Stud. 117:95-115.

Hoiczyk E (2000). Gliding motility in cyanobacteria: observations and possible explanations. Arch Microbiol. 174:11-17.

Ishida T, Watanabe MM, Sugiyama J, Yokota A (2001). Evidence for polyphyletic origin of the members of the orders of Oscillatoriales and Pleurocapsales as determined by $16 \mathrm{~S}$ rDNA analysis. FEMS Microbiol Lett. 201:79-82.

Kehoe DM (2010). Chromatic adaptation and the evolution of light color sensing in cyanobacteria. Proc Natl Acad Sci USA. 107:9029-9030.

Komárek J (2006). Cyanobacterial taxonomy: current problems and prospects for the integration of traditional and molecular approaches. Algae. 21:349-375.

Komárek J (2011). Some current problems of modern cyanobacterial taxonomy. Fottea. 11:1-7.

Komárek J (2013). Cyanoprokaryota Part 3: Heterocystous genera. In: Büdel B, Gärtner G, Krienitz L et al., editors: Süsswasserflora von Mitteleuropa. Heidelberg: Springer Spektrum:1131.

Komárek J (2016a). A polyphasic approach for the taxonomy of cyanobacteria: principles and applications. Eur J Phycol. 51:346-353. 
Komárek J (2016b). Review of the cyanobacterial genera implying planktic species after recent taxonomic revisions according to polyphasic methods: state as of 2014. Hydrobiologia. 764:259-270.

Komárek J, Anagnostidis K (1989). Modern approach to the classification system of Cyanophytes 4-Nostocales. Arch Hydrobiol Suppl. 82:247-345.

Komárek J, Anagnostidis K (1999). Cyanoprokaryota 1. Chroococcales. In: Ettl H, Gerloff I, Heynig H et al., editors: Süßwasserflora von Mitteleuropa. Jena: Gustav Fischer.

Komárek J, Kaštovský J, Mareš J, Johansen JR (2014). Taxonomic classification of cyanoprokaryotes (cyanobacterial genera) 2014, using a polyphasic approach. Preslia. 86:295-335.

Komárek J, Komárková-Legnerová J (1993). Radiocystis fernandoi, a new planktic cyanoprokaryotic species from tropical freshwater reservoirs. Preslia. 65:355-357.

Liu Z, Häder DP, Sommaruga R (2004). Occurrence of mycosporine-like amino acids (MAAs) in the bloom-forming cyanobacterium Microcystis aeruginosa. J Plankton Res. 26:963-966.

MacIntyre HL, Kana TM, Anning T, Geider RJ (2002). Photoacclimation of photosynthesis irradiance response curves and photosynthetic pigments in microalgae and cyanobacteria. J Phycol. 38:17-38.

Mareš J, Strunecký O, Bučinská L, Wiedermannová J (2019). Evolutionary patterns of thylakoid architecture in cyanobacteria. Frontiers Microbiol. 10.

Marquardt J, Palinska KA (2007). Genotypic and phenotypic diversity of cyanobacteria assigned to the genus Phormidium (Oscillatoriales) from different habitats and geographical sites. Arch Microbiol 187:397-413.

McGregor GB, Sendall BC (2015). Phylogeny and toxicology of Lyngbya wollei (Cyanobacteria, Oscillatoriales) from north-eastern Australia, with a description of Microseira gen. nov. J Phycol. 51:109-119.

Meffert M-E (1988). Limnothrix Meffert nov. gen. The unsheathed planktic cyanophycean filaments with polar and central gas vacuoles. Algol Stud. 50-53:269-276.

Moore KR, Magnabosco C, Momper L, Gold DA, Bosak T, Fournier GP (2019). An expanded ribosomal phylogeny of cyanobacteria supports a deep placement of plastids. Front Microbiol. 10.

Moustaka-Gouni M, Kormas KA, Vardaka E, Katsiapi M, Gkelis S (2009). Raphidiopsis mediterranea Skuja represents non-heterocytous life-cycle stages of Cylindrospermopsis raciborskii (Woloszynska) Seenayya et Subba Raju in Lake Kastoria (Greece), its type locality: evidence by morphological and phylogenetic analysis. Harmful Algae. 8:864-872.

Nabout JC, Rocha BdS, Carneiro FM, Sant'Anna CL (2013). How many species of Cyanobacteria are there? Using a discovery curve to predict the species number. Biodivers Conserv. 22:2907.

Nakayama T, Nomura M, Takano Y, Tanifuji G, Shiba K, Inaba K et al. (2019). Single-cell genomics unveiled a cryptic cyanobacterial lineage with a worldwide distribution hidden by a dinoflagellate host. Proc Nat Acad Sci USA. 116:15973-15978. 
Nishizawa T, Hanami T, Hirano E, Miura T, Watanabe Y, Takanezawa A et al. (2010). Isolation and molecular characterization of a multicellular cyanobacterium, Limnothrix/Pseudanabaena sp. strain ABRG5-3. Biosci Biotechnol Biochem. 74:1827-1835.

Nowicka-Krawczyk P, Mühlsteinová R, Hauer T (2019). Detailed characterization of the Arthrospira type species separating commercially grown taxa into the new genus Limnospira (Cyanobacteria). Sci Rep. 9:694.

Oren A, Garrity GM (2014). Proposal to change General Consideration 5 and Principle 2 of the International Code of Nomenclature of Prokaryotes. Int J Syst Evol Microbiol. 64:309-310.

Oren A, Gunde-Cimerman N (2007). Mycosporines and mycosporine-like amino acids: UV protectants or multipurpose secondary metabolites? FEMS Microbiol Lett. 269:1-10.

Oren A, Ventura S (2017). The current status of cyanobacterial nomenclature under the "prokaryotic" and the "botanical" code. Antonie van Leeuwenhoek:1-13.

Otsuka S, Suda S, Li R, Matsumoto S, Watanabe MM (2000). Morphological variability of colonies of Microcystis morphospecies in culture. J Gen Appl Microbiol 46:39-50.

Otsuka S, Suda S, Shibata S, Oyaizu H, Matsumoto S, Watanabe MM (2001). A proposal for the unification of five species of the cyanobacterial genus Microcystis Kützing ex Lemmermann 1907 under the Rules of the Bacteriological Code. Int J Syst Evol Microbiol. 51:873-879.

Pace NL (1997). A molecular view of microbial diversity and the biosphere. Science. 276:734-740.

Padisák J, Vasas G, Borics G (2016). Phycogeography of freshwater phytoplankton: traditional knowledge and new molecular tools. Hydrobiologia. 764:3-27.

Palinska KA, Deventer B, Hariri K, Lotocka M (2011). A taxonomic study on Phormidium-group (cyanobacteria) based on morphology, pigments, RAPD molecular markers and RFLP analysis of the 16S rRNA gene fragment. Fottea. 11:41-55.

Pathak J, Ahmed H, Singh SP, Häder D-P, Sinha RP (2019). Genetic regulation of scytonemin and mycosporine-like amino acids (MAAs) biosynthesis in cyanobacteria. Plant Gene. 17:100172.

Pereira S, Zille A, Micheletti E, Moradas-Ferreira P, De Philippis R, Tamagnini P (2009). Complexity of cyanobacterial exopolysaccharides: composition, structures, inducing factors and putative genes involved in their biosynthesis and assembly. FEMS Microbiol Rev. 33:917-941.

Pinevich AV (2015). Proposal to consistently apply the International Code of Nomenclature of Prokaryotes (ICNP) to names of the oxygenic photosynthetic bacteria (cyanobacteria), including those validly published under the International Code of Botanical Nomenclature (ICBN)/International Code of Nomenclature for algae, fungi and plants (ICN), and proposal to change Principle 2 of the ICNP. Int J Syst Evol Microbiol. 65:1070-1074.

Postius C, Ernst A (1999). Mechanisms of dominance: coexistence of picocyanobacterial genotypes in a freshwater ecosystem. Arch Microbiol. 172:69-75. 
Proteau P, Gerwick W, Garcia-Pichel F, Castenholz R (1993). The structure of scytonemin, an ultraviolet sunscreen pigment from the sheaths of cyanobacteria. Experientia. 49:825-829.

Rajaniemi P, Hrouzek P, Kastovska K, Willame R, Rantala A, Hoffmann L et al. (2005a). Phylogenetic and morphological evaluation of the genera Anabaena, Aphanizomenon, Trichormus and Nostoc (Nostocales, Cyanobacteria). Int J Syst Evol Microbiol. 55:11-26.

Rajaniemi P, Komárek J, Willame R, Hrouzek P, Kaštovská K, Hoffmann L et al. (2005b). Taxonomic consequences from the combined molecular and phenotype evaluation of selected Anabaena and Aphanizomenon strains. Algol Stud. 117:371-391.

Read N, Connell S, Adams DG (2007). Nanoscale visualization of a fibrillar array in the cell wall of filamentous cyanobacteria and its implications for gliding motility. J Bacteriol. 189:7361-7366.

Reynolds CS, Jaworsky GHM, Cmiech HA, Leedale GF (1981). On the annual cycle of Microcystis aeruginosa Kütz emend. Elenkin. Philos Trans R Soc Lond B. 293:419-477.

Rigonato J, Sant'Anna CL, Giani A, Azevedo MTP, Gama WA, Viana VF et al. (2018). Sphaerocavum: a coccoid morphogenus identical to Microcystis in terms of $16 \mathrm{~S}$ rDNA and ITS sequence phylogenies. Hydrobiologia. $811: 35-48$.

Rippka R, Deruelles J, Waterbury JB, Herdman M, Stanier RY (1979). Generic assignments, strain histories and properties of pure cultures of cyanobacteria. Microbiology. 111:1-61.

Salmaso N, Akçaalan R, Bernard C, Elersek T, Krstić S, Pilkaityte R et al. (2016a). Cyanobacterial species and recent synonyms. In: Meriluoto J, Spoof L, Codd GA et al., editors: Handbook on cyanobacterial monitoring and cyanotoxin analysis. Chichester: John Wiley \& Sons:489-500.

Salmaso N, Cerasino L, Boscaini A, Capelli C (2016b). Planktic Tychonema (Cyanobacteria) in the large lakes south of the Alps: phylogenetic assessment and toxigenic potential. FEMS Microbiol Ecol. 92:fiw155.

Shen H, Niu Y, Xie P, Tao M, Yang X (2011). Morphological and physiological changes in Microcystis aeruginosa as a result of interactions with heterotrophic bacteria. Freshwater Biol. 56:1065-1080.

Shih PM, Wu D, Latifi A, Axen SD, Fewer DP, Talla E et al. (2013). Improving the coverage of the cyanobacterial phylum using diversity-driven genome sequencing. Proc Natl Acad Sci USA. 110:1053-1058.

Śliwińska-Wilczewska S, Maculewicz J, Barreiro Felpeto A, Latała A (2018). Allelopathic and bloom-forming picocyanobacteria in a changing world. Toxins. 10:48.

Soo RM, Hemp J, Parks DH, Fischer WW, Hugenholtz P (2017). On the origins of oxygenic photosynthesis and aerobic respiration in Cyanobacteria. Science. 355:1436-1440.

Stanier RY, Sistrom WR, Hansen TA, Whitton BA, Castenholz RW, Pfennig N et al. (1978). Proposal to place the nomenclature of the cyanobacteria (bluegreen algae) under the rules of the international code of nomenclature of bacteria. Int J Syst Bacteriol. 28:335-336. 
Stanier RY, Van Niel CB (1941). The main outlines of bacterial classification. J Bacteriol. 42:437-466.

Stomp M, Huisman J, Voros L, Pick FR, Laamanen MJ, Haverkamp THA et al. (2007). Colourful coexistence of red and green picocyanobacteria in lakes and seas. Ecol Lett. 10:290-298.

Strunecký O, Elster J, Komárek J (2011). Taxonomic revision of the freshwater cyanobacterium "Phormidium" murrayi= Wilmottia murrayi. Fottea. 11:57-71.

Strunecký O, Komárek J, Elster J (2012). Biogeography of Phormidium autumnale (Oscillatoriales, Cyanobacteria) in western and central Spitsbergen. Polish Polar Res. 33:369-382.

Strunecký O, Komárek J, Johansen J, Lukešová A, Elster J (2013). Molecular and morphological criteria for revision of the genus Microcoleus (Oscillatoriales, Cyanobacteria). J Phycol. 49:1167-1180.

Strunecký O, Komárek J, Smarda J (2014). Kamptonema (Microcoleaceae, Cyanobacteria), a new genus derived from the polyphyletic Phormidium on the basis of combined molecular and cytomorphological markers. Preslia. 86:193-208.

Suda S, Watanabe MM, Otsuka S, Mahakahant A, Yongmanitchai W, Nopartnaraporn $\mathrm{N}$ et al. (2002). Taxonomic revision of water-bloom-forming species of oscillatoroid cyanobacteria. Int J Syst Evol Microbiol. 52:1577-1595.

Takaichi S (2011). Carotenoids in algae: distributions, biosyntheses and functions. Mar Drugs. 9:1101-1118.

Tandeau de Marsac N (1977). Occurrence and nature of chromatic adaption in cyanobacteria. J Bacteriol. 130:82-91.

Tandeau de Marsac N (2003). Phycobiliproteins and phycobilisomes: the early observations. Photosynth Res 76:197-205.

Tomitani A, Knoll AH, Cavanaugh CM, Ohno T (2006). The evolutionary diversification of cyanobacteria: molecular-phylogenetic and paleontological perspectives. Proc Natl Acad Sci USA. 103:5442-5447.

Turland NJ, Wiersema JH, Barrie FR, Greuter W, Hawksworth D, Herendeen PS et al., editors (2018) International Code of Nomenclature for algae, fungi, and plants (Shenzhen Code) adopted by the Nineteenth International Botanical Congress Shenzhen, China, July 2017. Koeltz Botanical Books, Gashütten. https://www.iapt-taxon.org/nomen/main.php

van Gremberghe I, Leliaert F, Mergeay J, Vanormelingen P, Van der Gucht K, Debeer AE et al. (2011). Lack of phylogeographic structure in the freshwater cyanobacterium Microcystis aeruginosa suggests global dispersal. PLoS One. 6:e19561.

Vandamme P, Pot B, Gillis M, De Vos P, Kersters K, Swings J (1996). Polyphasic taxonomy, a consensus approach to bacterial systematics. Microbiol Rev. 60:407-438.

Vieira JM, Azevedo MT, Azevedo SMFO, Honda RY, Correa B (2003). Microcystin production by Radiocystis fernandoi (Chroococcales, Cyanobacteria) isolated from a drinking water reservoir in the city of Belem, PA,) Brazilian Amazonia region. Toxicon. 42:709-713.

Vijayakumar S, Menakha M (2015). Pharmaceutical applications of cyanobacteriaa review. J Acute Med. 5:15-23. 
Wacklin P, Hoffmann L, Komárek J (2009). Nomenclatural validation of the genetically revised cyanobacterial genus Dolichospermum (Ralfs ex Bornet et Flahault) comb. nova. Fottea. 9:59-64.

Walsby AE (1994). Gas vesicles. Microbiol Rev. 58:94-144.

Wang W, Shen H, Shi P, Chen J, Ni L, Xie P (2016). Experimental evidence for the role of heterotrophic bacteria in the formation of Microcystis colonies. J Appl Phycol. 28:1111-1123.

Watanabe M, Semchonok DA, Webber-Birungi MT, Ehira S, Kondo K, Narikawa $\mathrm{R}$ et al. (2014). Attachment of phycobilisomes in an antenna-photosystem I supercomplex of cyanobacteria. Proc Natl Acad Sci USA. 111:2512-2517.

Welker M, von Döhren H (2006). Cyanobacterial peptides - Nature's own combinatorial biosynthesis. FEMS Microbiol Rev. 30:530-563.

Whitton BA, Potts M (2000). The ecology of cyanobacteria: their diversity in time and space. Heidelberg: Springer.

Wilmotte A (1994). Molecular evolution and taxonomy of the cyanobacteria. In: Bryant DA, editors: The molecular biology of cyanobacteria. Dordrecht: Kluwer Academic Publishers:1-25.

Wilmotte A, Laughinghouse IV DH, Capelli C, Rippka R, Salmaso N (2017). Taxonomic identification of cyanobacteria by a polyphasic approach. In: Kurmayer R, Sivonen K, Wilmotte A et al., editors: Molecular tools for the detection and quantification of toxigenic cyanobacteria. Chichester: John Wiley \& Sons:79-134.

Woese C (1987). Bacterial evolution. Microbiol Rev. 51:221-271.

Woese C, Kandler O, Wheelis ML (1990). Towards a natural system of organisms: proposals for the domains Archaeea, Bacteria, and Eucarya. Proc Natl Acad Sci USA. 87:4576-4579.

Zapomělová E, Hrouzek P, Řezanka T, Jezberová J, Řeháková K, Hisem D et al. (2011). Polyphasic characterization of Dolichospermum spp. and Sphaerospermopsis spp. (Nostocales, Cyanobacteria): morphology, $16 \mathrm{~S}$ rRNA gene sequences and fatty acid and secondary metabolite profiles. J Phycol 47:1152-1163.

Zapomělová E, Skácelová O, Pumann P, Kopp R, Janeček E (2012). Biogeographically interesting planktonic Nostocales (Cyanobacteria) in the Czech Republic and their polyphasic evaluation resulting in taxonomic revisions of Anabaena bergii Ostenfeld 1908 (Chrysosporum gen. nov.) and A. tenericaulis Nygaard 1949 (Dolichospermum tenericaule comb. nova). Hydrobiologia. 698:353-365.

Zwart G, Kamst-van Agterveld MP, Werff-Staverman I, Hagen F, Hoogveld HL, Gons HJ (2005). Molecular characterization of cyanobacterial diversity in a shallow eutrophic lake. Environ Microbiol. 7:365-377. 